\title{
Investigation of Opportunities for High-Temperature Solar Energy in the Aluminum Industry
}

Subcontract Report NREL/SR-550-39819

May 2006

\section{August 1995}

J. Murray

Portland State University

Portland, Oregon 


\title{
Investigation of Opportunities for High-Temperature Solar Energy in the Aluminum Industry
}

\section{August 1995}

\author{
J. Murray
}

Portland State University

Portland, Oregon

NREL Technical Monitor: A. Lewandowski

Prepared under Subcontract No. XCK-5-15114-00 
This publication was reproduced from the best available copy Submitted by the subcontractor and received no editorial review at NREL

\section{NOTICE}

This report was prepared as an account of work sponsored by an agency of the United States government. Neither the United States government nor any agency thereof, nor any of their employees, makes any warranty, express or implied, or assumes any legal liability or responsibility for the accuracy, completeness, or usefulness of any information, apparatus, product, or process disclosed, or represents that its use would not infringe privately owned rights. Reference herein to any specific commercial product, process, or service by trade name, trademark, manufacturer, or otherwise does not necessarily constitute or imply its endorsement, recommendation, or favoring by the United States government or any agency thereof. The views and opinions of authors expressed herein do not necessarily state or reflect those of the United States government or any agency thereof.

Available electronically at http://www.osti.gov/bridge

Available for a processing fee to U.S. Department of Energy and its contractors, in paper, from:

U.S. Department of Energy

Office of Scientific and Technical Information

P.O. Box 62

Oak Ridge, TN 37831-0062

phone: 865.576 .8401

fax: 865.576 .5728

email: mailto:reports@adonis.osti.gov

Available for sale to the public, in paper, from:

U.S. Department of Commerce

National Technical Information Service

5285 Port Royal Road

Springfield, VA 22161

phone: 800.553 .6847

fax: 703.605.6900

email: orders@ntis.fedworld.gov

online ordering: http://www.ntis.gov/ordering.htm 


\begin{abstract}
This report gives the conclusions drawn from a study of the potential application of hightemperature solar process heat for production of aluminum. I have reviewed the most important thermal aspects of alternative aluminum process technologies as they have been published either in technical literature or in patents. This work is not, therefore, a true feasibility study of a new, solar-based aluminum process. Rather, it is a preliminary technical examination and summary of the thermal portions of the enormous number of processes studied over the last 120 years for the manufacture of aluminum, coupled with an examination of the nature and position of the aluminum industry in the U.S. today to determine whether a process based on the use of hightemperature solar process heat might be received with interest at this time.

Many processes would be feasible with solar process heat. I based my recommendations for further study on three criteria:

1) the proposed process should have been substantially researched by one of the major American-based aluminum companies

2) The use of solar process heat might solve technical or process problems previously encountered

3) The use of high-temperature solar energy could be a critical component in the economic or technical success of the process.
\end{abstract}

In addition, I looked for processes that might adapt easily to the use of high-temperature solar energy. In particular, in my experience, this meant:

1) The process did not require tight temperature control for its success

2) The process could be conducted at atmospheric pressure

3) The process could be operated without a windowed receiver; that is it did not require extremely tight atmospheric control either for the process itself or for the likely materials of construction

4) High-temperature heat storage would not be necessary for process success. 24-hour operation would either not be absolutely critical, or the process could be performed with two or more distinct steps, one of which could run continuously if desired

Based on these criteria, I have recommended three processes as particularly suitable for the use of high-temperature solar energy as process heat. For one of these, a carbothermic reduction process as described in Kibby's Reynolds Metals Company patents, the thermal energy provided by highly-concentrated sunlight is the only process energy required. For the other two processes, a reduction to an aluminum-silicon alloy as described in Alcoa/DOE research publications and reduction to an AlN intermediate compound, the product of the thermal portion of the process still requires some electric process energy for the production of aluminum metal. 


\section{Table of Contents}

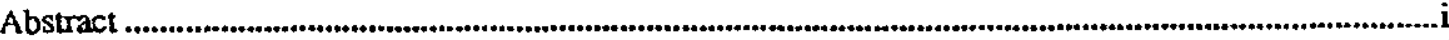

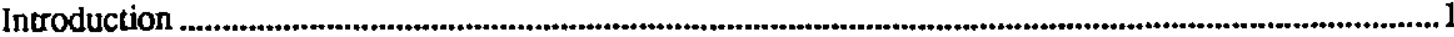

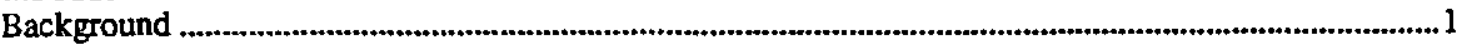

The structure of the three components of aluminum production-

Bauxite mining ..................................................................................................................................

Bayer Process ............................................................................................................................1

Hall-Héroult Process.............................................................................................................

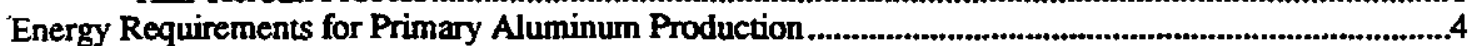

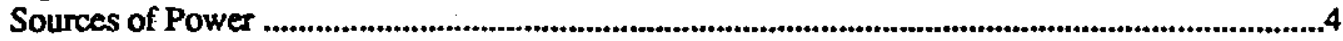

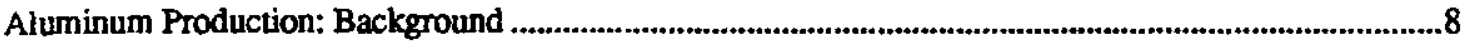

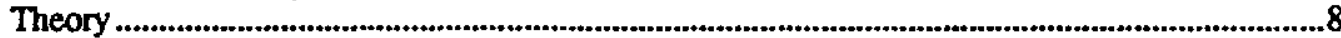

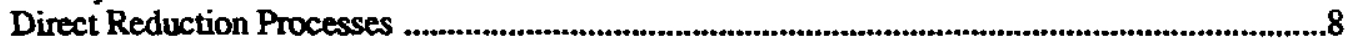

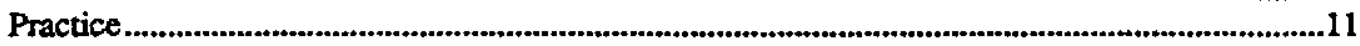

Why should the DOE and Aluminum Companies be Interested in an Altemative Process? ........................13

1) Capital costs are related to volumetric productivity ..............................................................13

2) International competitiveness of aluminum industry determined by costs of production

3) Hall-Hérouly/Bayer processes are mature technologies .............................................................14

4) Development of a more environmentaily friendly process ...........................................................17

Unique Opportunities for Solar Energy ...................................................................................................17

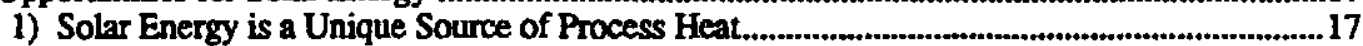

2) The Solar Advantage: fixed costs...............................................................................................17

3) Drastic Reduction of $\mathrm{CO} 2$ Emissions ...........................................................................18

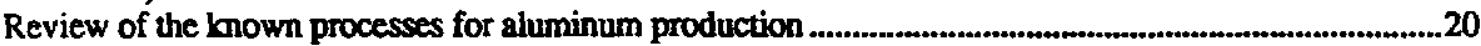

Reduction/Reaction Dry Processes that primarily replace the Bayer Process to give $\mathrm{Al}_{2} \mathrm{O}_{3} \ldots . . .20$

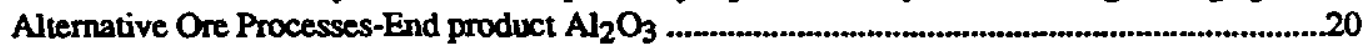

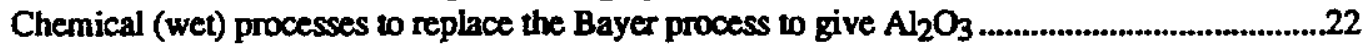

Altemative Processes-End product Aluminum or Aluminum Alloy .............................................24

Thermal process to form an intermediate, followed by electrolysis...................................................27

Identifying Processes with the Best Potential for Solar Process Heat ...........................................................28

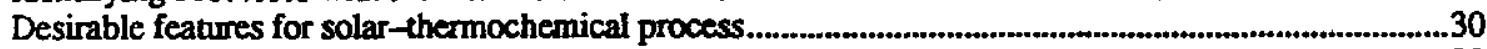

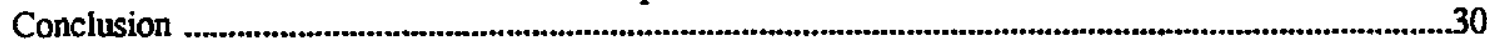

Processes with excellent potential for high-temperature solar process heat ................................................30

Process \#1: Alcoa Al-Si alloy reduction process ......................................................................30

Process \#2: Reynolds Carbothermal Reduction .........................................................................30

Process \#3: Carbothermal production of AlN Intermediate ..........................................................31

Appendix A: Interviews with Process Managers and Researchers at Alcoa, Kaiser and Reynolds ...........32

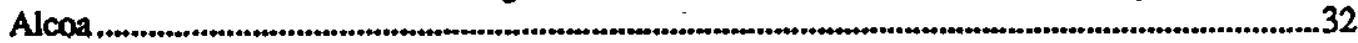

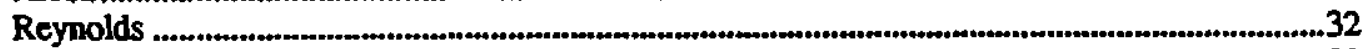

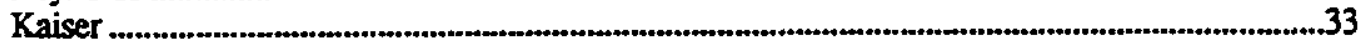

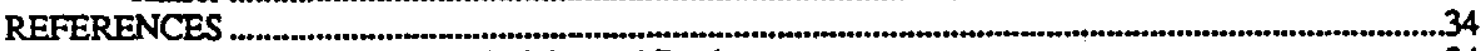

Review and General Background Articles and Books ................................................................................34

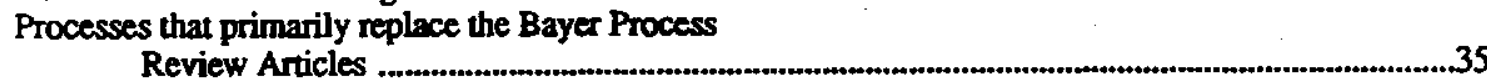

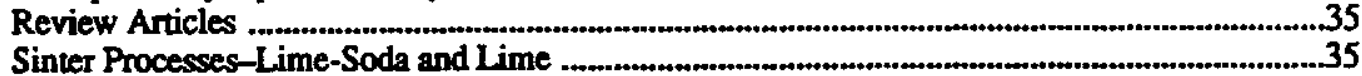

H+ Process . .

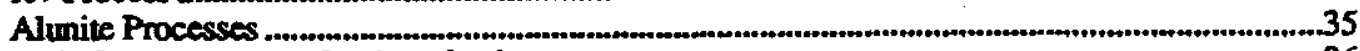

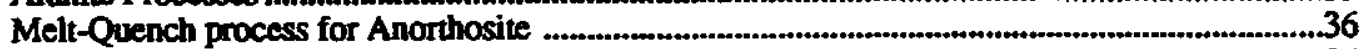

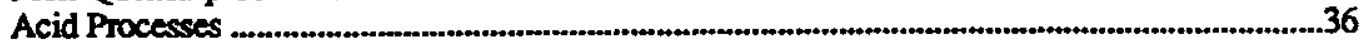

Processes that Replace the Hall-Heroult Process to make Aluminum
Direct Thermal Processes for Aluminum Production..............................................................36

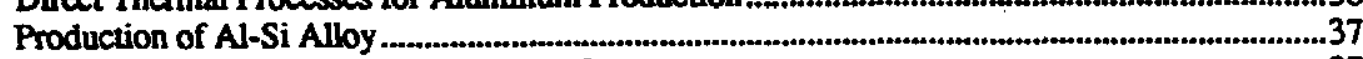

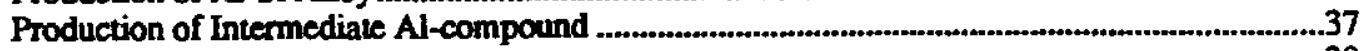

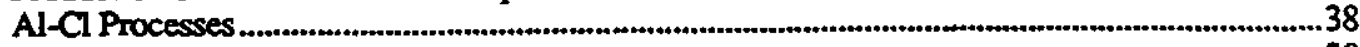

Aluminum Purification Processes..........................................................................................38

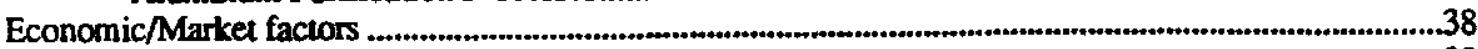

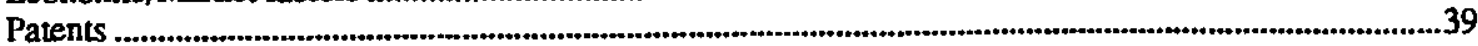




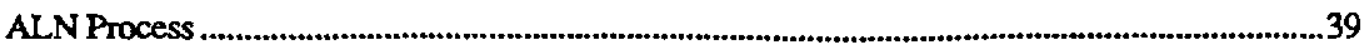

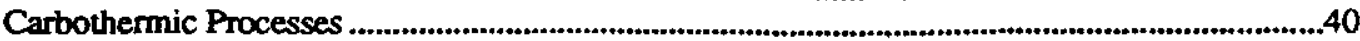

Reynolds Cartothermic Process ..........................................................................................40

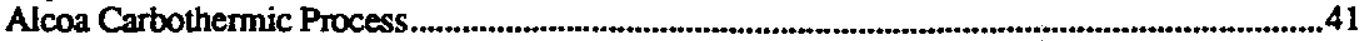

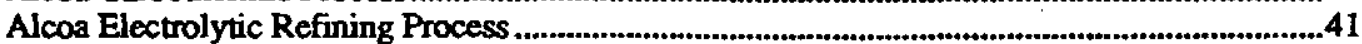

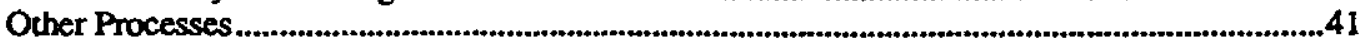

List of Figures and Tables

Fig. 1. Distribution of currently known reserves of bauxite worldwide ..............................................2

Fig. 2. Distribution of primary aluminum capacity for the big 3 producers in US ............................... 3

Fig. 3. Total final consumption of energy, electricity by industry in OECD nations ................................5

Fig. 4. The relative energy contents for aluminum and other competing materials ...............................6

Fig. 5. Location of U.S. primary aluminum smelters ..........................................................................6

Fig. 6. Source of electricity consumed by primary aluminum industry in OECD nations ........................7

Fig. 7. Theoretical energy required to produce aluminum from alumina for Hall, ASP processes ..........8

Fig. 8a. Total energy to make metal from several oxides ....................................................................9

Fig. 8b. Total energy to make intermediate compound from alumina; energy required to electrolyze

compound to form aluminum

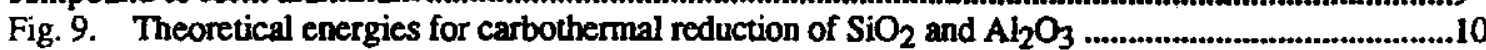

Fig. 10. Theoretical energies in $\mathrm{kWh} / \mathrm{kg} \mathrm{Al}$ to produce $\mathrm{Al}$ via three processes: $\mathrm{Hall}$, ASP and AIN ........11

Fig. 11. Flow of energy and materials for Bayer \& Hall process ................................................................12

Fig. 12. Market price for metals showing effect of its abundance and method for production ..................13

Fig. 13. Price of aluminum ingot in US market 1954-1991 .................................................................15

Fig 14. Altemate forms of aluminum cre superimposed on solar flux map of US.................................16

Fig 15 Processes that primarily replace the Bayer Process .............................................................................19

Fig 16 Processes that result in production of aluminum or alloy ...................................................................23

Fig. 17. System concept for solar process .........................................................................................29

Table 1. Primary aluminum producers in the United States for 1993..................................................3

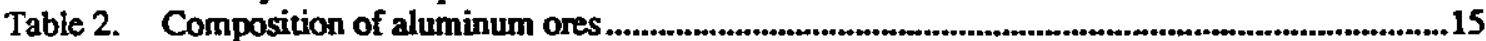

Table 3. Summary of iarge-scale experiments and commencial carbothermal process plants .................25 


\section{Introduction}

The scope of this study was to review altemative aluminum process technologies and recommend those most suitable for the use of high-temperature solar energy as process heat. This work is not, therefore, a true feasibility study of a new aluminum process. Rather, it is a preliminary technical examination and summary of the thermal portions of the enormous number of processes studied over the last 120 years for the manufacture of aluminum, coupled with an examination of the nature and position of the aluminum industry in the U.S. today to determine whether a process based on the use of high-temperature solar process heat might be received with interest at this time. I expected that a positive finding would result in a short list of suitable candidate processes, and I included exploratory contacts with the major aluminum companies to assess their interest in altemative processes. Finally, where the needs for further research to adapt a process to concentrated solar energy process heat were clear to me, I provide a recommended course of action for further technical research.

To achieve these goals, there were three questions that needed to be answered:

1) Why should the aluminum industry be interested in an altemative process, and why might they also consider an alternative process based on solar energy?

2) Why should the Department of Energy (and ultimately the U.S. policy makers) be interested in supporting the development of an alternative aluminum process based on high-temperature solar energy?

3) What is the nature of highly concentrated solar energy used for process heat and what makes a process a candidate for high-temperature solar process heat?

\section{Background}

The structure of the three components of aluminum production-Bauxite mining; Bauxite to alumina (Bayer Process) and Alumina to aluminum (Hall-Héroult Process)

The aluminum industry is highly concentrated and vertically integrated. Even though aluminum is the most common metallic element found in the earth's crust, the aluminum industry today relies bauxite, a form of its ore found in tropical and formerly tropical areas. The majority of alumina is produced from bauxite via the Bayer Process, developed nearly a century ago. World reserves of bauxite are currently surprisingly concentrated, fig. 1 . The majority of the world's reserves are located in the four countries Australia (21.2\%), Guinea (26.7\%), Brazil (10.7\%), and Jamaica (9.5\%) (Barham, Bunker and O'Hearn, 1994). Around half, therefore, comes from developing countries in Africa, Latin America and the Caribbean. Only Australia and Brazil produce enough alumina to meet their own needs, the other countries rely on imports. This represents a shift from the earlier part of the century, when known reserves were concentrated in industrial nations: the United States, France and Northern Ireland. By 1950, reserves of 1,605 million metric tons had been discovered in 27 countries. The reserves were still concentrated, but in more remote locations. Of the world's total reserves at that time, over half was to be found in only four countries: Jamaica(20\%), Hungary (15.6\%), Ghana (14.3\%), and Brazil (12\%). The reserves of Ireland had been totally depleted, and the U.S. and French reserves amounted to only $2.5 \%$ and $3.7 \%$, respectively, of the world's total. This dramatic shift in the location of known reserves from the industrialized nations to the developing ones has resulted in a significant shift in the strategies of firms to gain control of bauxite extraction and processing, and also in the geography of smelter locations. Since 1974 there has been an attempt on the part of bauxite-producing countries to impose some control on the price and production of bauxite through the formation of the International Bauxite Association, often referred to as the bauxite cartel. (Peck, 1988)

At the alumina stage, production shifts from bauxite producing nations to industrialized nations, where about half the alumina refining capacity is located. At the smelting stage, the 
major aluminum consuming nations dominate with about $70 \%$ of primary aluminum production located in the U.S., Canada, Europe and Japan. Although the various production stages are technologically and geographically distinct, they are often linked by vertical integration, as all of the major aluminum companies, for example, own bauxite mines, alumina processing and aluminum smelting facilities (Peck, 1988). Joint ventures have been the next most favored alternative to within-firm ownership, and long-term contracts the last alternativ (Barham, 1994).

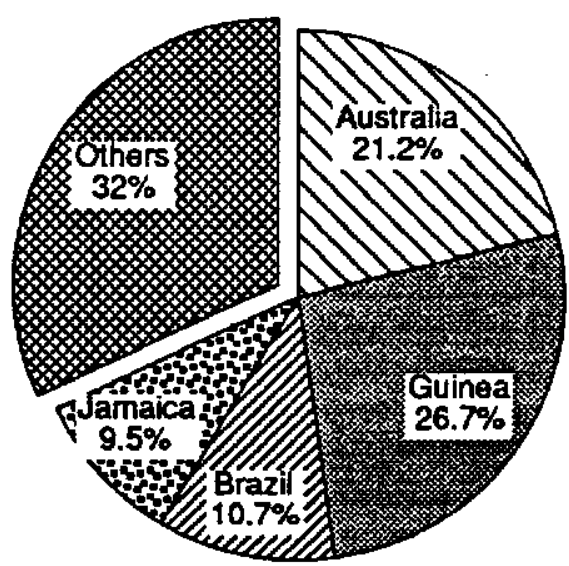

Percent World Bauxite Production

Fig. 1. Currently known world reserves of bauxite. The four major bauxite nations, Guinea, Australia, Brazil, and Jamaica hold $68 \%$ of the bauxite reserves.

The aluminum industry is highly concentrated and vertically integrated. As of 1960 , six firms accounted for most of the world's aluminum production (although there were 20 other producers). The big six were Alcoa(U.S.), Alcan(Canada), Kaiser Aluminum and Chemical Company(U.S.), Pechiney(France), Reynolds Metals Company (U.S.), Schweizerische Aluminium AG (Alusuisse; Switzerland). These six companies owned or controlled $45 \%$ of the western world's bauxite, $62.5 \%$ of its alumina production and $52.5 \%$ of the primary aluminum production. The tendency from the 1960's through the 80's has been away from the concentration of the first stage (mining/alumina/aluminum) with increased involvement by the companies in later phases of aluminum transformations.

As new producers have entered the market, the number of aluminum producers has increased from 26 in 1960 to 71 in 1981 . Since then, particularly as the enormous production capacity of the emerging nations of the former Soviet Union have been felt in the aluminum market, the market share for the big six has declined further.

There are 10 primary aluminum producers in the U.S.; Alcoa, Reynolds, Kaiser, Alumax, Noranda, Ormet, International Light Metals Corporation, TST Inc. TIMCO, Alcan and National Southwire, table 1. The three largest, historically Alcoa, Reynolds and Kaiser, have always held an oligopolistic position in the aluminum industry. In 1960 the big three were responsible for around $87 \%$ of total U.S. capacity; currently this market share is down to about $60 \%$, as shown in fig. 2.(Kennedy, 1985) All three are vertically integrated from the bauxite mining stage through to the final fabricated product. All have major foreign holdings. 


\section{Energy Requirements for Primary Aluminum Production}

The primary aluminum industry is one of the most energy-intensive industrial sectors worldwide, fig. 3. Most of the energy consumed by the aluminum industry is required for the smelting stage, and is used in the form of electricity for the electrolysis of alumina. The energy required to make aluminum is compared to that required for other competing materials in fig. 4. Production of aluminum accounts for around $4 \%$ of total electricity production for the Organization for Economic Cooperation and Development (OECD) countries, ${ }^{\dagger}$ and is higher for some countries. In Norway, for example, aluminum production consumes $16 \%$, and in Iceland it consumes $44 \%$ of the national electricity produced (OECD, 1983).

\section{Sources of Power}

Aluminum smelting facilities in the US are located near relatively cheap and abundant sources of electric power, fig. 5. About $35 \%$ of US capacity is located in the Pacific Northwest, in the Bonneville Power Administration's (BPA) service area and 14\% in the Tennessee Valley Authority's (TVA) area because of Federal hydropower. The remaining half of US capacity is supplied by about 20 different power organizations. The two largest are the New York-State Power Authority and the Big Rivers Electric Corporation in Kentucky. Smelters are found in the Ohio Valley because of cheap coal resources, and around the Gulf coast because of access to cheap natural gas and proximity to the Southern bauxite regions. Both areas afford access to cheap transportation. The other area of concentration, New York state, offers cheap hydropower from Niagara Falls.

Historically, the aluminum companies have controlled the profitability of aluminum by shifting their production to nations and smelters with the cheapest, most secure power or other favorable arrangements. In the U.S., Alcan recently acquired a smelter, Pechiney and Alusuisse sold its interests in U.S. smelting facilities. In Western Europe, all six own smelters. In Australia the big six account for most of the smelting capacity through joint ownership with local interests. In Brazil both Alcoa and Alcan own smelters. Alcan was dominant in Canada until 1980, owning all but one of the smelters, but since 1980 all of the big six have plans to build smelting capacity in Canada.

Hydropower is the most important source of cheap electricity for the aluminum industry. Figure 6 shows that in 1981, about $52.6 \%$ of the power consumed by the primary aluminum industry in the Western world came from hydropower. Coal-generated electricity contributed another $27.5 \%$, nuclear-generated power about $6 \%$, and oil and gas represented about 6.8 and 7.2 percents, respectively. When OECD and non-OECD nations are considered separately, however, the energy sources are quite different. Non-OECD nations relied much more heavily on hydropower with nearly $73 \%$ of the electricity consumed coming from this resource. Canada has been extremely successful in attracting new smelter construction, and as seen in fig. 6, the entire industry in Canada relies on hydropower. In 1981, coal supplied about $30.5 \%$ of the electricity to OECD smelters, a result mainly of the U.S. situation.

\footnotetext{
† The OECD nations are Australia, Austria, Belguim, Canada, Denmark, Finland, France, Germany, Greece, Iceland, Ireland, Italy, Japan, Luxembourg, the Netherlands, New Zealand, Norway, Portugal, Spain, Sweden, Switzerland, Turkey, the United Kingdom, and the United States.
} 

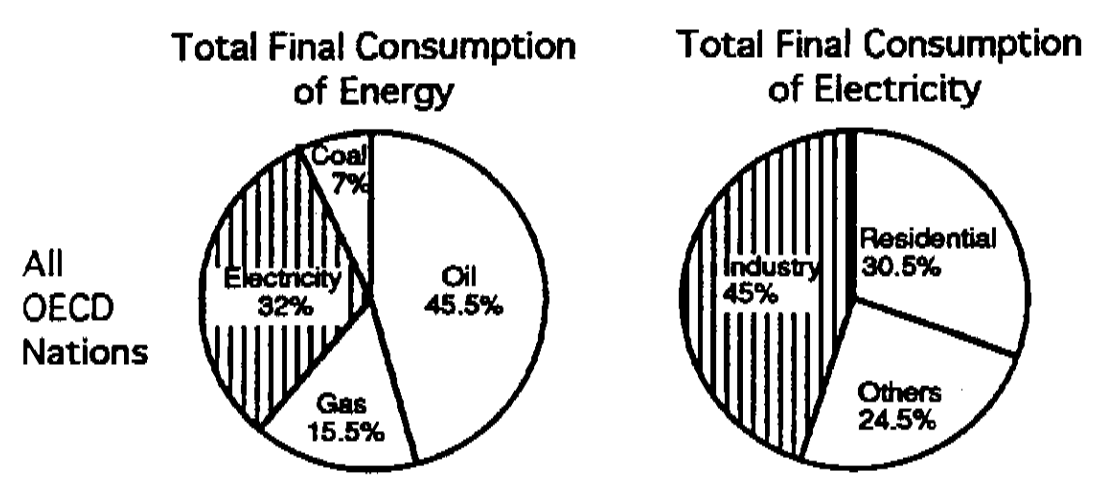

Final Consumption of Electricity by Industry
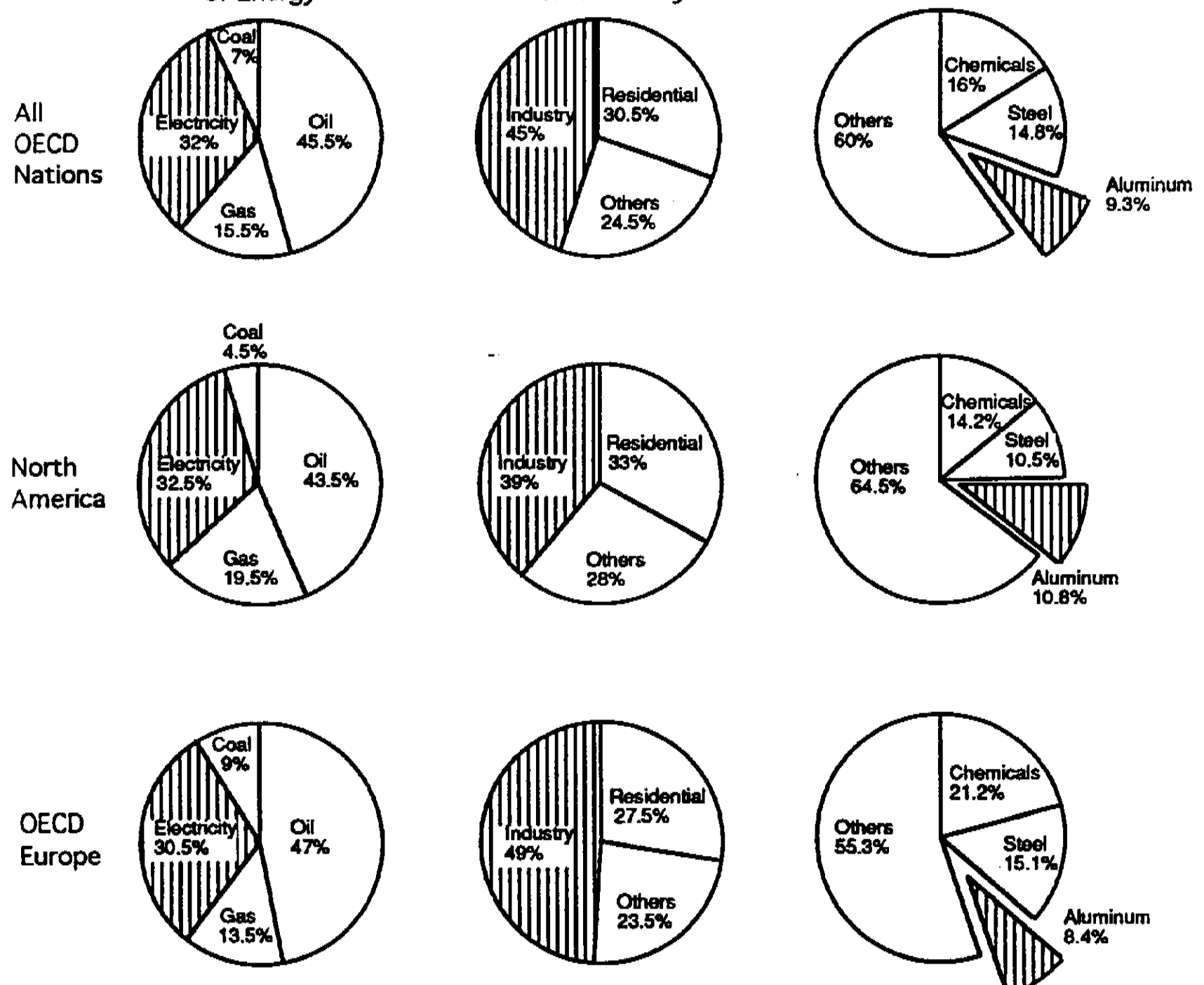

OECD

Europe
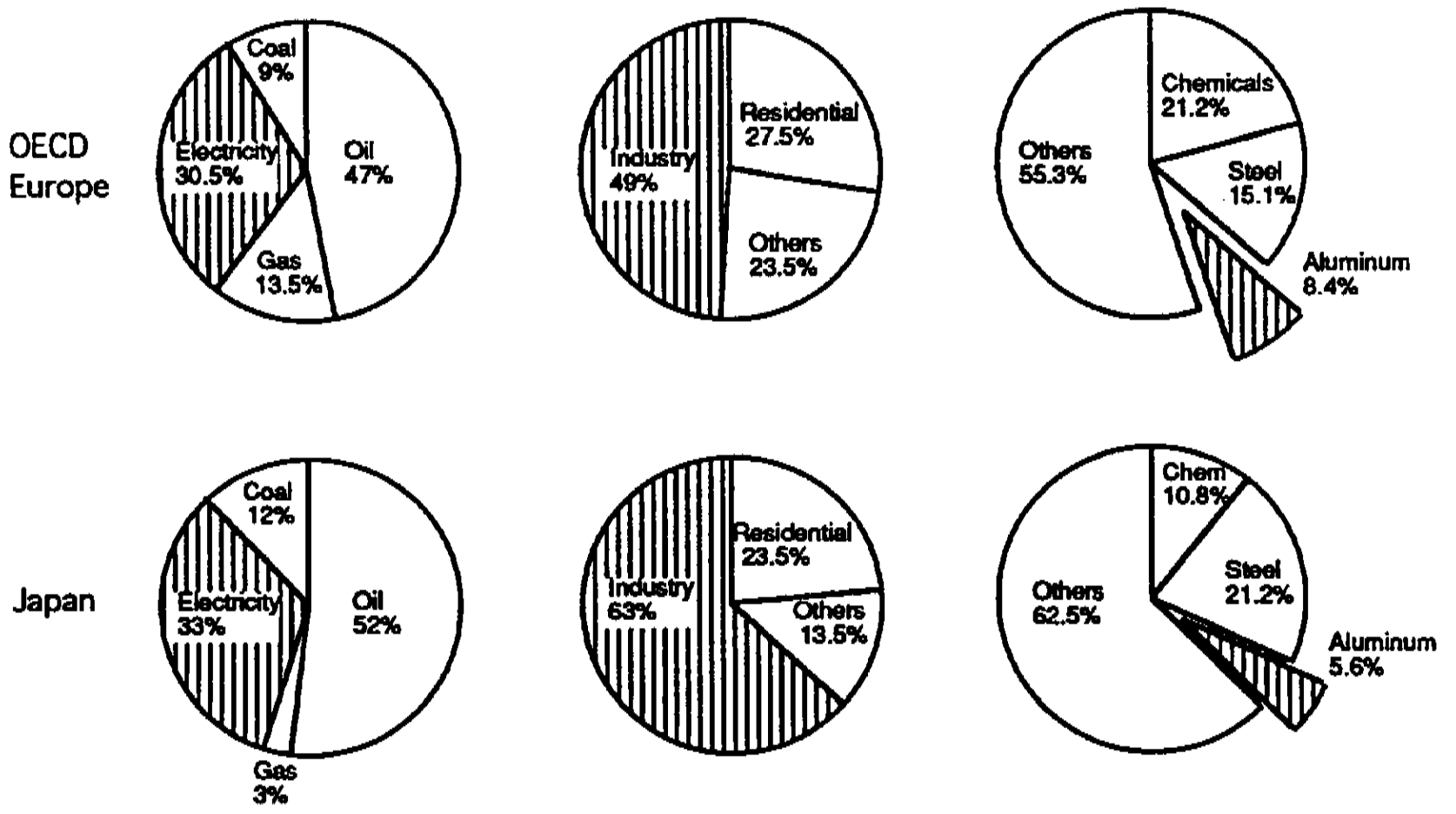

Fig. 3. Electricity consumption by the aluminum industry in the OECD and Japan for 1980 . European and North American nations are shown separately. Source: OECD "Aluminum Industry: energy aspects of structural change", 1983. 


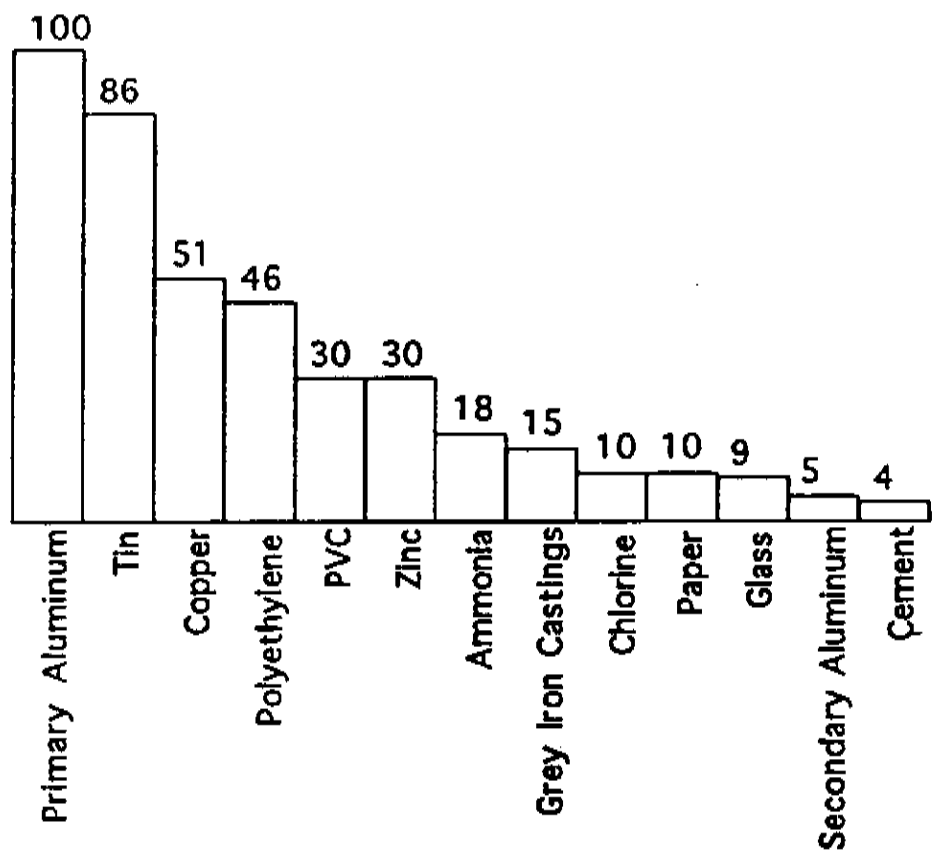

Fig. 4. The relative cnergy contents for aluminum and other materials compared on a weight basis. The energy content of aluminum has been assigned the value of 100; the other materials are adjusted accordingly.

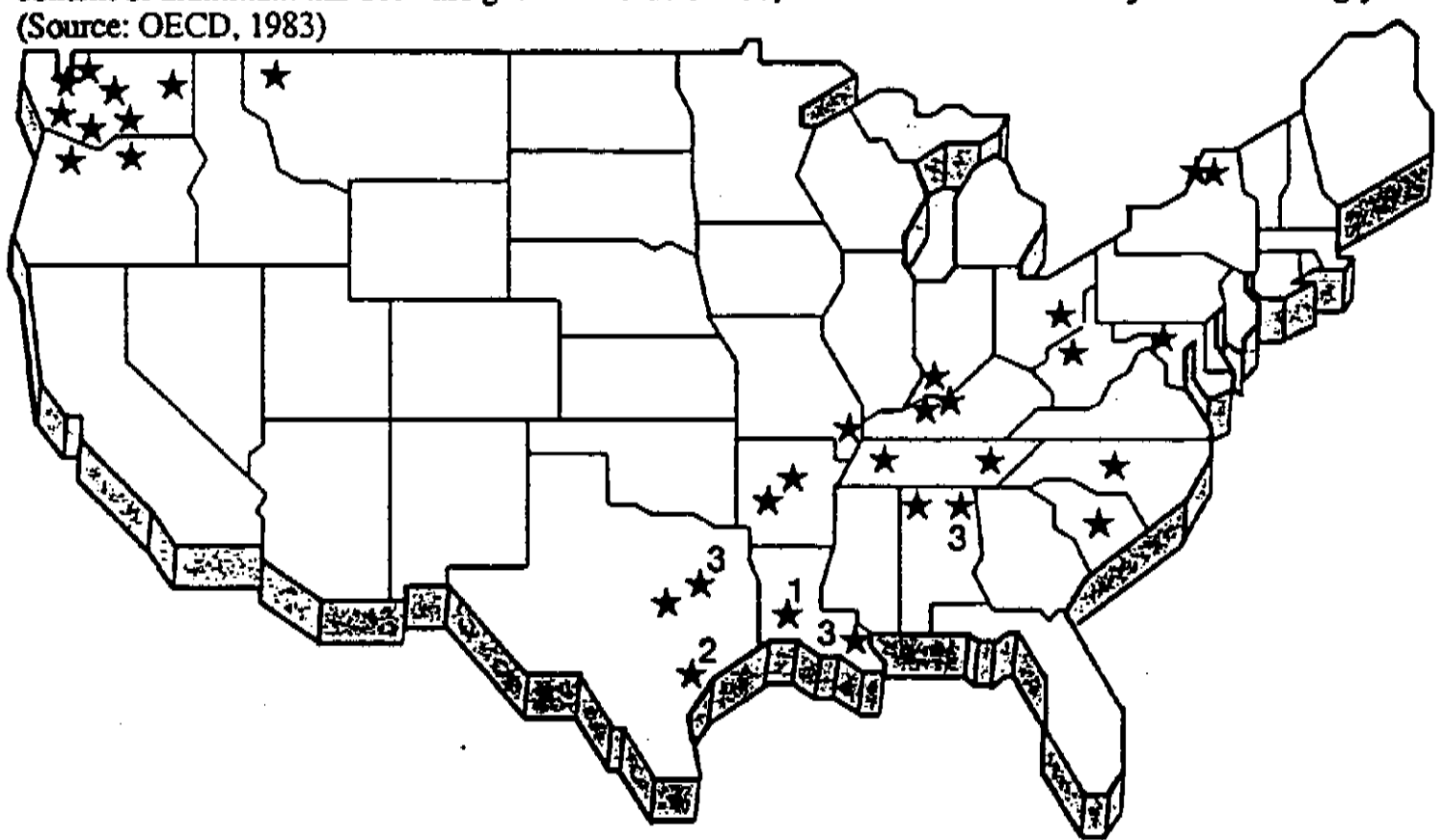

' Lake Charles, La_Reynolds acquired this 33,000 ton facility from Consolldated in 1983 for its carbon anode plant closed since September 1981.

${ }^{2}$ Reynolds 103,000 ton Corpus Christl smelter's permanent closing announced In early 1884; the smelter had been closed since May 1981.

'Alcoa's 15,000 ton Palestine, Texas plant, Revere's 105,000 ton Scottsboro, Alabama plant, and Kalser's 236,000 to Chaimette, La, plant remained closed in 1984. Kalser has written off part of the Chalmette, La, capacity.

Fig. 5. Location of U.S. primary aluminum smelters. Smelters are clustered around abundant scurces of cheap electricity such as hydropower from the TVA, Niagara Falls and BPA or coal-generated electricity in the Ohio River valley. Source:Kennedy, 1985 and the American Aluminum Association. 


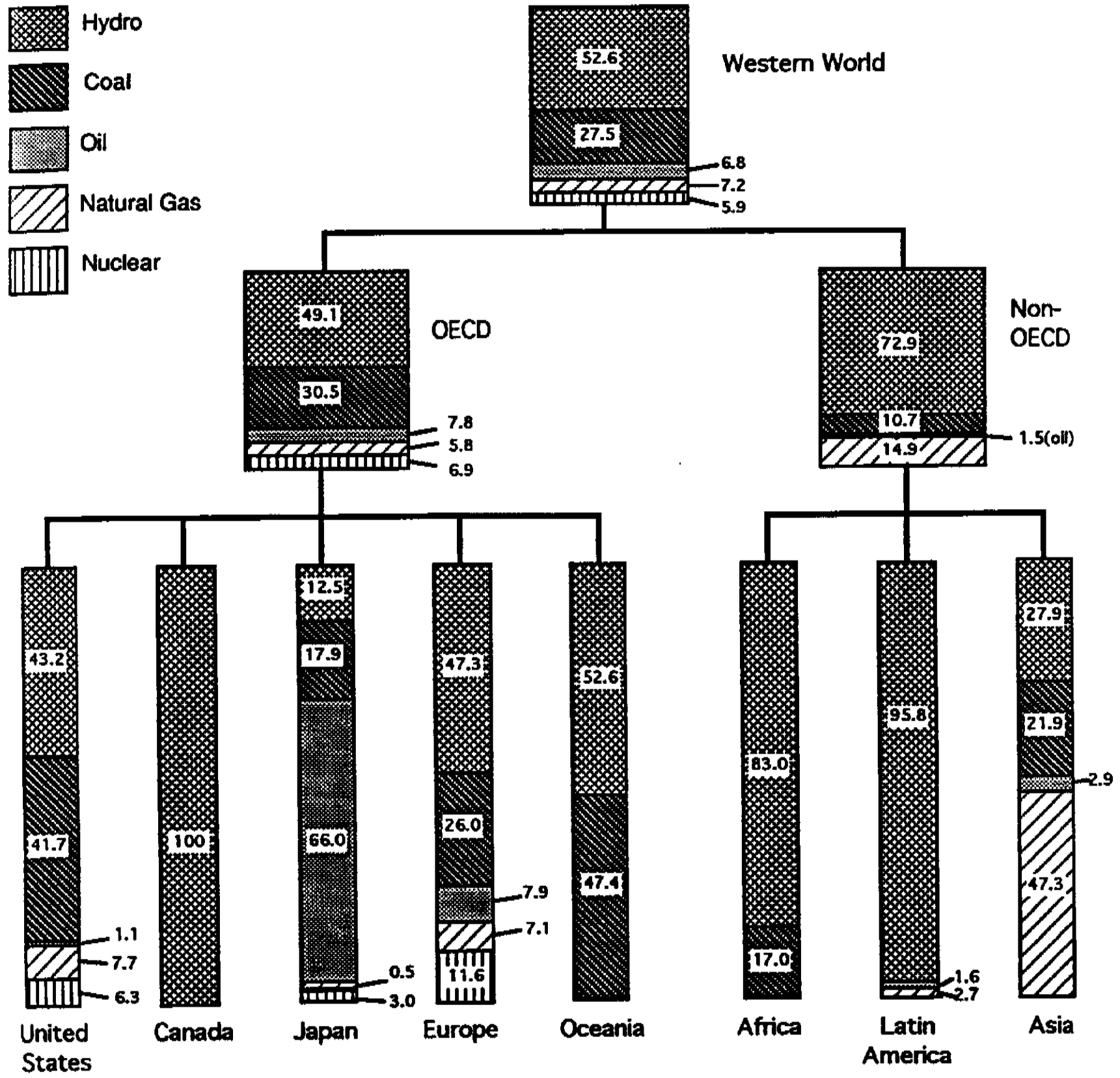

Fig. 6. Source of electricity consumed by the aluminum industry in the OECD and Japan for 1980. European and North American nations are shown separately to illustrate the different mix of energy sources prevailing. Source: OECD "Aluminum Industry: energy aspects of structural change", 1983. 


\section{Aluminum Production: Background}

\section{Theory}

The direct production of metals by reduction of their oxides are high-temperature, energy-intensive processes. The total amount of energy required is the enthalpy change for the reaction $\Delta \mathrm{H}$. Of this total, as shown in fig. 7, an amount equal to the Gibbs free energy change of the reaction $\Delta G$ may have to be supplied as high-quality energy, for example, in the form of electrical work or by introducing a reducing agent. The remainder, $\Delta \mathrm{H}-\Delta \mathrm{G}$, may be supplied relatively inexpensively as process heat. Where electrical work is required, it must typically be obtained from a high-temperature thermal reservoir created by the combustion of fuels, however the efficiency of such conversion is restricted by Camot law. It is, therefore, thermodynamically wasteful to use electrical energy, or the equivalent Gibbs free energy of a reducing agent, in excess of what is required by $\Delta G$ of the reaction in order to compensate for the additional process heat needed. Frequently that is the case in many commercial electrolytic processes and reducing furnaces with the result that the energy cost is a substantial portion of the value of the final product.

Research efforts to find a direct thermal method for making aluminum from its ore or from alumina are as old as the industry itself. Though some technical success has been achieved, generally processes have failed economically because they required very high temperature process heat that could only be supplied electrically.

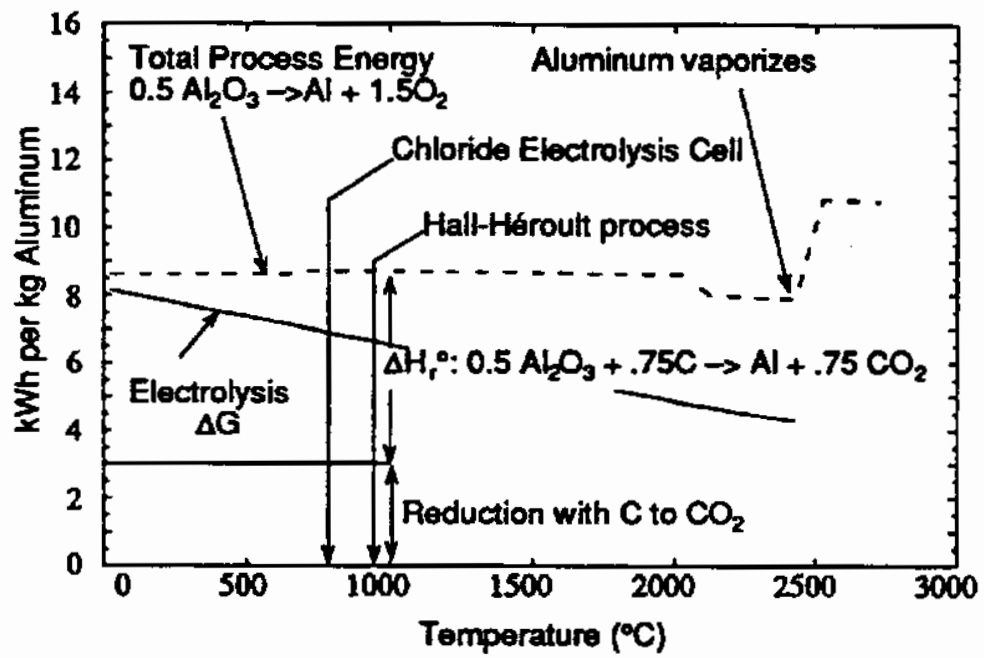

Fig. 7. Theoretical energy required to produce aluminum from alumina. The types of energy required over the temperature range at which the Hall-Heroult cell operates are, from cheapest to most expensive:

$\begin{array}{rlc}\begin{array}{c}\text { Energy form } \\ \text { thermal energy }\end{array} & =25 \% \text { of total } & \text { Cost } \\ \text { Chemical reduction energy (C) } & =35 \% \text { of total } & 4 \\ \text { Electrolysis energy } & =40 \% \text { of total } & 16\end{array}$

\section{Direct Reduction Processes}

Several difficulties are encountered in the attempt to design a single thermal process to make aluminum along the lines of a carbothermal blast-furnace process used for other metals. Compared to other metal oxides $\mathrm{Al}_{2} \mathrm{O}_{3}$ is very stable. The temperature required for its reduction with carbon would be in the range $2000-2200^{\circ} \mathrm{C}$. The energy required for any process to make one g-mole of metal from its oxide is shown in fig. 8a. The energy required to make aluminum is nearly the highest shown at around $200 \mathrm{kcal} / \mathrm{gmole}$. This fact alone does not prevent the development of a successful process-a carbothermal process to make silicon exists, requiring more energy than aluminum. There is no way to decrease this amount of energy; the only option 
the process designer has is to attempt to find a series of steps that might apportion the energy economically among the available sources: thermal, chemical or electrical.

There are three main problems that must be addressed before a direct reduction process will be commercially viable. The first is that the temperature at which appreciable reduction of $\mathrm{Al}_{2} \mathrm{O}_{3}$ occurs is also very near the temperature at which the metal is a vapor, and significant losses of $\mathrm{Al}$ would be expected in the vapor phase as the suboxide $\mathrm{Al}_{2} \mathrm{O}(\mathrm{g})$, or as $\mathrm{Al}(\mathrm{g})$. This is not an insurmountable problem, as shown by the success of the Imperial Smelting Process, where zine is recovered as a vapor. The problem of metal loss in the form of a volatile intermediate has been solved in the commercially successful carbothermal process to make Si from its oxide. Even higher losses of $\mathrm{Si}$ metal appearing as $\mathrm{SiO}$ are predicted, but $\mathrm{Si}$ metal is commercially produced in a submerged-arc carbothermal process. The main obstacle to developing a viable thermal reduction process for aluminum seems to be that the Al-C-O system at high temperatures forms a partly liquid-partly solid oxide- and carbide-containing melt with little or no aluminum recovered. This presents a major technical challenge in the design of a reactor/furnace to augment the production of $\mathrm{Al}$, and creative attempts to solve these difficulties appear in, for example, the patents awarded to Kibby et al. The third problem that must be solved is that $\mathrm{Al}_{4} \mathrm{C}_{3}$ is soluble in the metal at the temperatures at which the reduction occurs in amounts roughly equal to $20-37 \% \mathrm{Al}_{4} \mathrm{C}_{3}$ by weight, producing a liquid product that is difficult to pour. Since one of the main goals of any successful direct reduction process is to recover aluminum in a substantially pure state, this level of contamination with the carbide represents a major diseconomy for the process.

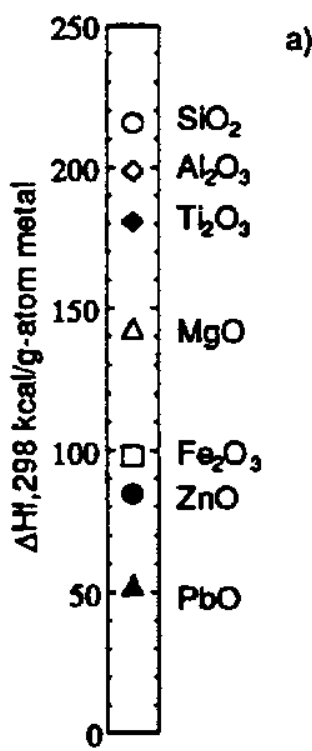

a)

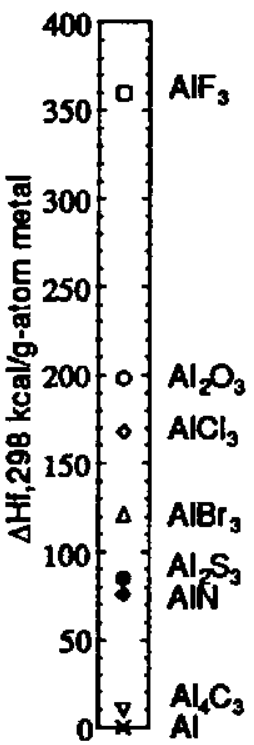

Fig. 8. The left-hand graph shows the total energy each of the metals $\mathrm{Al}, \mathrm{Fe}, \mathrm{Mg}, \mathrm{Pb}, \mathrm{Si}$, $\mathrm{Ti}$ and $\mathrm{Zn}$ require to win one g-atom of metal from the respective oxides. The right-hand graph shows the strategy that might be used in considering a process design to form an intermediate compound from the oxide $\mathrm{Al}_{2} \mathrm{O}_{3}$. The distance from the candidate intermediate to $\mathrm{Al}_{2} \mathrm{O}_{3}$ is a measure of the total amount of energy that must be expended to form that intermediate. The distance from the intermediate to Al is a measure of the energy that must be expended to win the metal from the intermediate. One can see that it would take a good deal of thermal energy 10 form $\mathrm{AlN}$ from $\mathrm{Al}_{2} \mathrm{O}_{3}$, but comparatively litule electrical energy to electrolyze the AlN to Al and $\mathrm{N}_{2}$. (Approach adapted from Cochran, 1987, data from JANAF tables)

A combustion-heated coke-fired process would produce about 18 tons of $\mathrm{CO}$ per ton $\mathrm{Al}$ produced. This causes several difficulties. Alcoa found, in an experimental program to make an $\mathrm{Al}-\mathrm{Si}$ alloy by direct reduction of $\mathrm{Al}_{2} \mathrm{O}_{3}-\mathrm{SiO}_{2}$ containing ores, that this large flow of reducing gas effectively prevented the formation of metal in the combustion-heated blast furnace. Volatile $\mathrm{SiO}$ and $\mathrm{Al}_{2} \mathrm{O}$ species carried off the $\mathrm{Al}$ and $\mathrm{Si}$ at the elevated temperatures from the reaction zone, then caused severe reactor problems by condensing and "bridging" the reactor outlet. 
Because of the large amounts of $\mathrm{CO}$ produced by this process, to be economic it would have to be considered as a $\mathrm{CO}$ or $\mathrm{H}_{2}$ cogenerating process. Furthermore, any impurities present in the $\mathrm{C}$ source appear in the metal or alloy metals produced. In some processes, this dictates the use of petroleum coke for a pure $\mathrm{C}$ source, and further hurts the economy of the process. These are all problem that a solar heated process might solve, since the process could be conducted with the stoichiometric required amounts of $\mathrm{C}$, or with $\mathrm{CH}_{4}$ as the reducing agent. Bureau of Mines researchers found that wood waste was catalytic in some cases as a carbon source for Al-Si alloy production; a solar heated process would require far less wood waste than a combustion heated process, so this may be a feasible alternative to pure coke.

Fig.9 shows the energy required to make $\mathrm{Al}$ from $\mathrm{Al}_{2} \mathrm{O}_{3}$ via the theoretical equation $\frac{1}{2} \mathrm{Al}_{2} \mathrm{O}_{3}+\frac{3}{2} \mathrm{C} \rightarrow \mathrm{Al}+\frac{3}{2} \mathrm{CO} ; \Delta \mathrm{G}=0 @ \sim 2000^{\circ} \mathrm{C}$; and compares it to the same process for the production of $\mathrm{Si}$. The Al-producing reaction does not proceed in this way; most likely carbides and oxycarbides are formed which then are reduced to the metal, but even if this were an accurate picture of how the $\mathrm{Al}$ might be produced, it is clear from fig. 9 that the reaction will not proceed using thermal energy alone until temperatures well above $2000^{\circ} \mathrm{C}$. These are the process temperatures used in the experimental, coke-fired blast furnace research in Japan, and proposed in Kibby's patents.

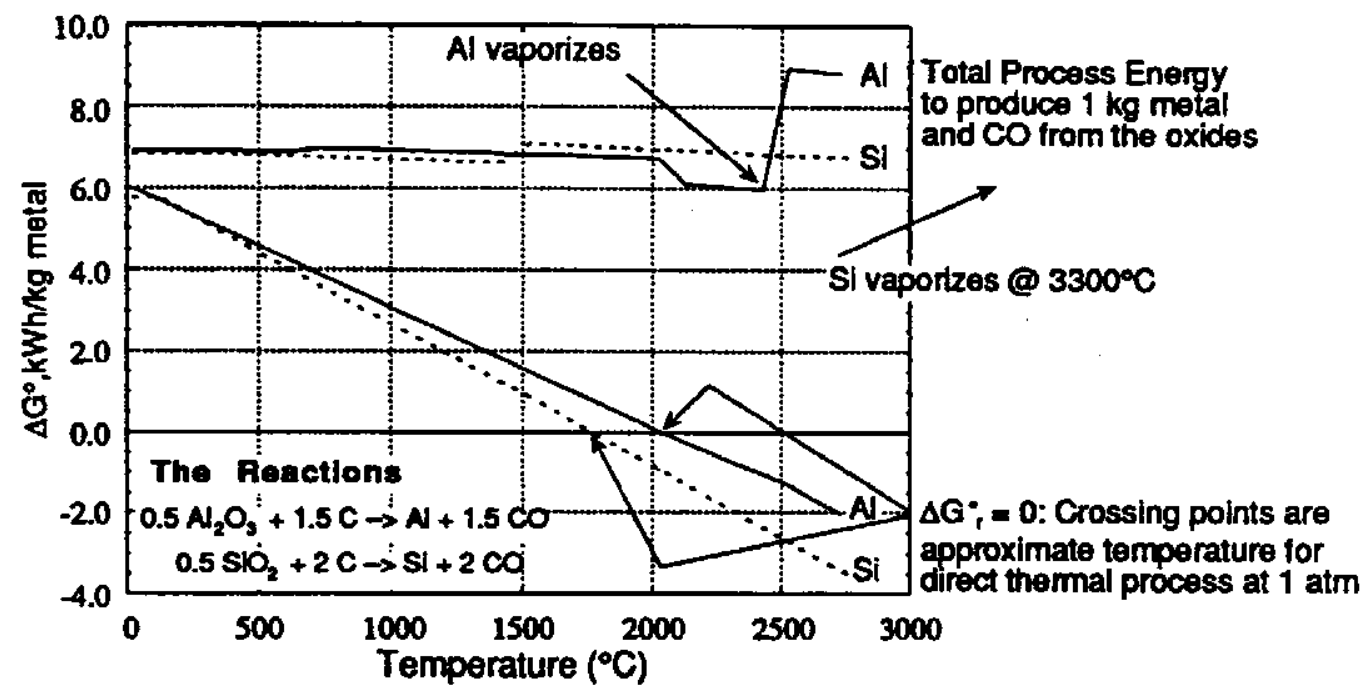

Fig. 9. Theoretical energies in $\mathrm{kWh}$ per $\mathrm{kg}$ metal produced that are required to convert $\mathrm{Al}_{2} \mathrm{O}_{3}$ to $\mathrm{Al}$ and $\mathrm{SiO}_{2}$ to Si for a carbothermal process with $\mathrm{CO}$ as the product gas. The figure illustrates two points. First, that there is no relationship between the temperature required for a process and the energy. Si may be produced at about $1750^{\circ} \mathrm{C}$, where Al requires process temperatures of about $2000^{\circ} \mathrm{C}$. The reduction of $\mathrm{SiO}_{2}$ requires more energy than the reduction of $\mathrm{Al}_{2} \mathrm{O}_{3}$ to $\mathrm{Al}$ metal. Second, Si vaporizes at a very high temperaure while $\mathrm{Al}$ is very likely to be present as a vapor at the temperature required for the thermal reduction process. There is a successful commercial carbothermic process for Si production; as yet, none has been implemented for Al though it is thecretically possible.

One strategy might be to form an intermediate compound using thermal energy, then electrolyze or chemically reduce that intermediate. This is the approach that most of the alternative processes use. Figure $8 \mathrm{~b}$ shows how one might choose among possible compounds. The distance from $\mathrm{Al}_{2} \mathrm{O}_{3}$ to the intermediate compound is the total energy that must be supplied to form the compound, and the closer the compound is to $\mathrm{Al}$ the less energy that must be expended to electrolyze the compound to produce the metal. The Hall-Heroult process uses a combination of electrical and chemical to reduce $\mathrm{Al}_{2} \mathrm{O}_{3}$ to $\mathrm{Al}$. If an intermediate such as $\mathrm{AlN}$ could be formed thermally, then far less electrical energy would be required to win the metal 
than currently used in the Hall-Héroult process. Figure 10, taken from Cochran's paper, shows how three processes, the Alcoa chloride process, the Hall-Héroult, and a potential AlN electrolysis process apportion the energy.

Another strategy is to use thermal energy to produce an alloy of aluminum, then remove the aluminum from the alloy using a thermal process, chemical process or electrolytic process. Examples of all three of these approaches are discussed in the technology review section.

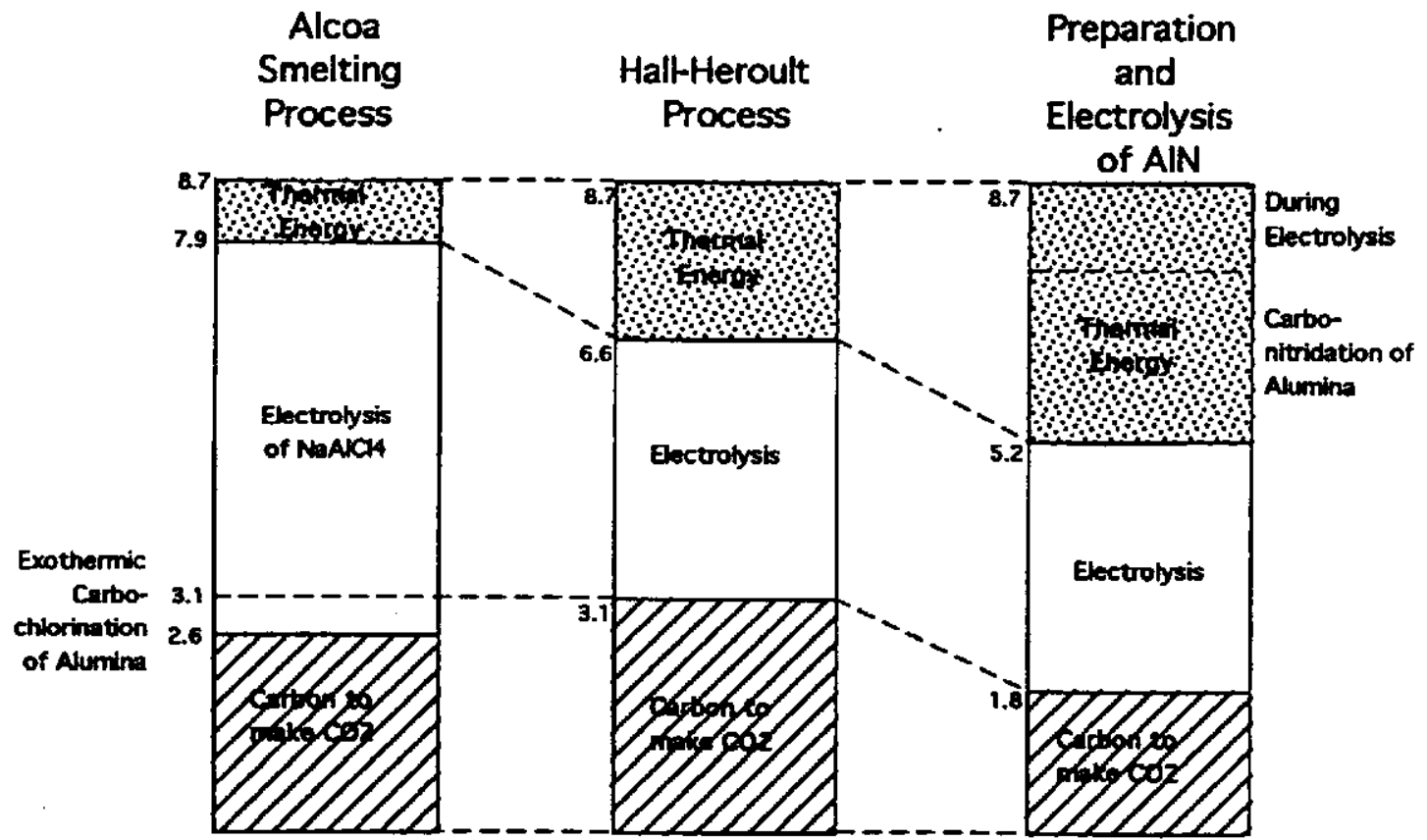

Fig. 10. Theoretical energies in $\mathrm{kWh} / \mathrm{kg} \mathrm{Al}$ required to convert $\mathrm{Al}_{2} \mathrm{O}_{3}$ to $\mathrm{Al}$ for three processes: the Alcoa chloride process. The Hall-Héroult process and a new process that might prepare AlN carbothermally for Practice electrolysis to $\mathrm{Al}$ and $\mathrm{N}_{2}$. (Cochran, 1987)

The production of aluminum from its ore at present relies on two processes developed in the late 1800's,: the Bayer process which produces pure alumina from bauxite ore, and the HallHéroult process which produces aluminum from alumina. The Bayer process uses about a quarter of the total energy requirement. Most of this energy is thermal. The cost of the Bayer process represents about $27 \%$ of the cost of aluminum production. The Hall-Heroult process uses about three quarters of the total energy. Most of this energy is electrical energy. The cost of the Hall-Héroult process represents between 20 and $40 \%$ of the cost of aluminum production for U.S. manufacturers (Cochran, 1987).

The Hall-Heroult process dominates the technology of producing aluminum. It is primarily an electrolytic process in which pure alumina $\left(\mathrm{Al}_{2} \mathrm{O}_{3}\right)$ dissolved in cryolite, a double fluoride of aluminum and sodium Na3AlF6, is reduced electrically and chemically at about $960^{\circ} \mathrm{C}$. The electric power is supplied through carbon electrodes which extend into the molten salts bath, and the carbon in the electrodes also serves to reduce the $\mathrm{Al}_{2} \mathrm{O}_{3}$. Electric power is thus saved at the expense of carbon consumption, with the disadvantage that any impurities in the electrode carbon will show up in the final metal. This adds expense since the consumable electrodes must be made of very pure carbon.

Figures 7 and 9 illustrate the theoretical energy required to produce aluminum from alumina as a function of temperature. The amount of energy represented at the vertical line labeled Hall-Héroult at $960^{\circ} \mathrm{C}$ has three segments. The energy supplied from the carbon reducing electrodes that form $\mathrm{CO}_{2}$ at the temperature at which the cell is operated, is shown at around $3.1 \mathrm{kWh} / \mathrm{kg} \mathrm{Al}$. Theoretically, around $3.5 \mathrm{kWh} / \mathrm{kg} \mathrm{Al}$ should be supplied electrically, and 
the remainder, about $2.1 \mathrm{kWh} / \mathrm{kg} \mathrm{Al}$ could then come from thermal sources. Unfortunately, modern Hall-Heroult cells are still so inefficient (about $40-45 \%$ based on the theoretical) that all of this energy is added from the electric source. The thermal energy generated through this inefficiency must be removed from the cell, and this need to remove energy actually limits the ability to gain an economy of scale since it limits the size of the cell that may be used (conversation with Cochran).

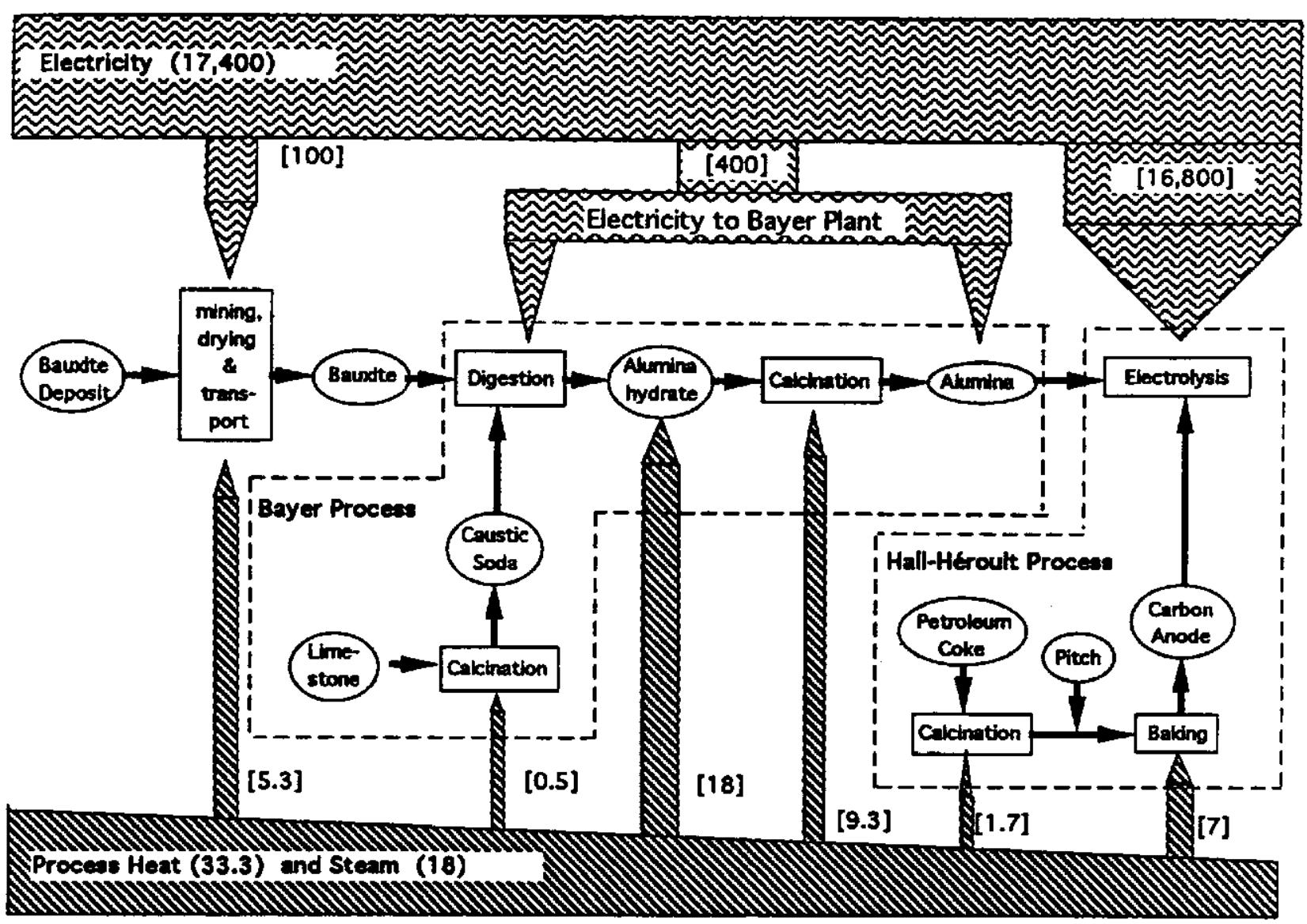

Fig. 11. Flow of energy and materials required for the Bayer and Hall-Heroult processes. The amount of electrical energy required can be as high as $17,400 \mathrm{kWh} /$ metric ton for an older plant. The approximate amounts of energy for each stage are given in figure. The energy remaining is used in casting the aluminum ingots; the final stage of aluminum production.

The Hall-Heroult process also relies on a starting feed of pure alumina, the majority of which is produced from bauxite by the Bayer process. Typical energy requirements per metric ton of aluminum are shown in fig. 11 (OECD, 1976). It is important to distinguish betwcen thermal and electric forms of energy since the costs of electrical energy are about sixteen times greater than the costs for a combustion-heated thermal process (Aggarwal and Sinek). 


\section{Why should the DOE and Aluminum Companies be Interested in an Alternative Process?}

\section{1) Capital costs are related to volumetric productivity: Hall-Héroult is very low}

According to Cochran, metals produced by thermal processes have the lowest market price. The market for aluminum in the past has expanded by replacing the use of other metals (and materials) when the cost of aluminum has decreased due to technological improvements to the process. The volume productivity of a process has the strongest effect on capital and labor requirements, the two leading cost sectors for the primary aluminum industry. Because the HallHerroult cell only produces aluminum on the planar surface of the cathode its productivity is about 0.0014 volume aluminum per hour per unit cell volume. This is only about $10 \%$ of the productivity of a blast furnace, where the metal is produced in a three-dimensional zone of the reactor. The 14-bipolar chloride cell of the Alcoa Smelting Process (ASP), at 0.004 volume aluminum per hour per unit cell volume, was an improvement, but it introduced other cost factors that finally made it uneconomic. The process complexity and process stream volume are two other strong influences on capital costs. Processes like the ASP that require gas-phase streams or liquid solutions entail large increases in the process stream volume.(Cochran,

2) International competitiveness of aluminum industry determined by costs of production: Hall-Héroult based industry is dependent on availability of cheap, plentiful electricityElectrolytic processes are inherently more expensive than thermal

Next to a metal's abundance in the earth's crust, the most important factor in determining price is the method of production used. Metals that are produced thermally have the lowest price, and this increases by a factor of between 4 and 23 for metals that must be electrolytically produced, as seen in fig. 12 taken from Cochran's paper(Cochran, 1987).

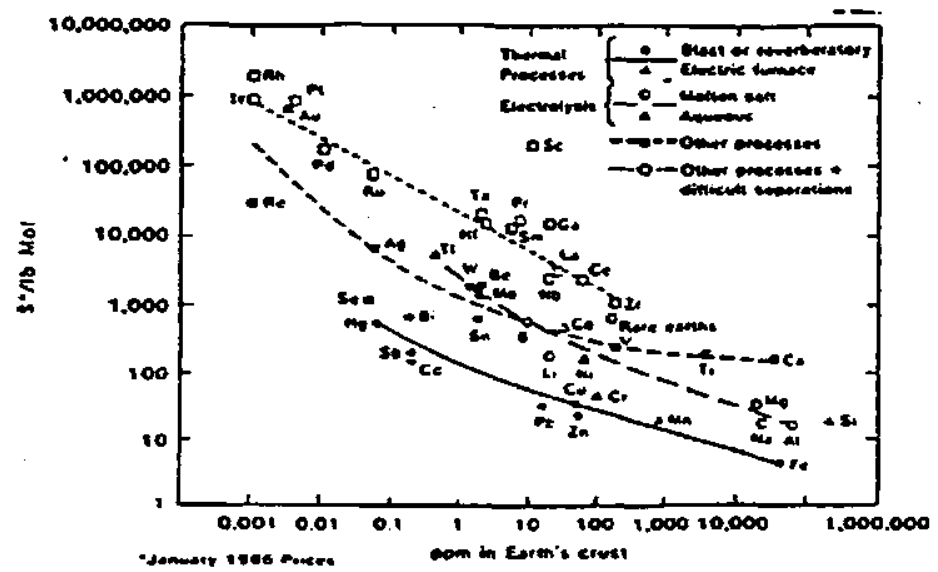

Fig. 12. Market price for metals showing the effects on price of the average abundance of the metal in the earth's crust and the methods used for producing it.

The main motivation for continued interest in an alternative process is that the international competitiveness of the U.S. aluminum industry is determined by the costs of production; for the Hall-Heroult process these are dominated by the costs of energy. Advantage in the aluminum industry is overwhelmingly determined by access to cheap power. It is not only the present cost that is important, however, but the assessment of future variability in the cost of electric power. The U.S., with its diverse and decentralized policy and regulation of electric price, and varied ownership of electric generating capacity is perceived as entailing a higher risk than countries with public ownership.

The U.S. after the oil price shocks of the 70's has lost competitiveness in the international arena for construction of new smelters, with such activity moving to Australia, Brazil and 
Canada. The last new smelter in the US was constructed in the 1960's (Peck, 1988). Merton Peck, economist at Yale University, in his book "The World Aluminum Industry in a Changing Energy Era" suggests that the U.S. industry is most likely also in the process of losing competitiveness for the operation of existing smelters due to high energy costs. In the case of hydropower in the Pacific Northwest, this is dependent both on natural availability, demand from other customers, and public policy decisions that fix the price aluminum smelters pay for power. Peck notes:

"Aluminum smelting is a capital-intensive production process. Consequently, there is a significant difference between two definitions of costs: unit operating costs and total unit costs. Unit operating costs are the costs that can be avoided by not operating the smelter. In order of general importance, the principal components of aluminum smelter operating costs are alumina, electricity, labor, and other raw materials. Total unit costs include capital costs, as well as items like property taxes and insurance, which apply whether the smelter operates or not.

Operating costs are the costs primary producers consider when deciding whether or not to operate a smelter. A simple statement of a producer's decision criterion is that a smelter is operated if its unit operating costs are equal to or less than the current price for aluminum. Unless that condition is met the firm can reduce its losses by closing the smelter. It is often profitable for a firm to operate a smelter even though the price of aluminum is less than the total unit cost (the smelter in that instance operates at a loss by conventional accounting standards). This situation arises because, as noted above, the total unit cost includes costs that are incurred whether the smelter operates or not. Hence the loss would be even greater if the smelter were not operated. Because aluminum smelting is a capitalintensive process, the gap between unit operating and total unit costs is substantial......

Smelters with very high unit operating costs are called swing capacity smelters and are usually operated only when prices are high.

3) Hall-Héroult/Bayer processes are mature technologies; opportunity for cost savings are incremental only

The costs and energy usage figures for the present processes, taken with the fact that the Bayer/Hall-Heroult process is a mature technology that is most likely approaching a real lower limit in costs and process improvements, provide much of the motivation in the search for an alternate smelting process. Further motivation comes from the intense competition both within the worldwide aluminum industry and new competition with emerging, lower-cost materials. (Cochran, 1987). Figure 13 gives the price per pound for aluminum sold in the US market.t This plot illustrates several points. The cost of aluminum ingot on the world market has fluctuated by a factor of two even when considered in terms of constant dollars over the period 1954-1991. This fluctuation has forced the closing of many aluminum smelters, even in the Pacific Northwest where the costs of electricity are especially low. A steady decrease in the real cost of aluminum is also apparent during the post-war years as the process was made ever more efficient.

Figure 13 also shows one of the challenges that any new aluminum process must meetnot only must it compete with the Hall-Héroult process, but it must be economic enough through the lows in the aluminum market to pay off investment costs in new facilities. Cochran estimates this would mean that the costs for any new process would have to be almost half of the

\footnotetext{
I I have adjusted the prices to 1991 values using the Marshall and Swift index, published monthly in Chemical Engineering. Over the years this index has worked better than other more general indices such as the CPI or CE's index to adjust dollar values for the Chemical and Process Industry.
} 
average Bayer-Hall-Héroult process to allow profitable operation through the lows in the price cycle for aluminum (Cochran, 1987). Cochran points out that there is no single cost factor in the current process that amounts to the required reduction, so any new process will have to significantly reduce several cost factors simultaneously. For this reason, and also because the energy costs in the Hall-Héroult process are equal to the Bayer production costs, I have widened the scope of my study to include alternative processes that (perhaps preferentially) begin with the aluminum ore and end with the metal. The added advantage, should such a process be feasible, is that the U.S. is relatively poor in bauxite and quite rich in other aluminum-containing ores such as kaolin clays, anorthosite, laterites and others. The chemical composition and mass percentage of $\mathrm{Al}_{2} \mathrm{O}_{3}$ contained in some of the prospective alumina sources are shown in table 2 . Figure 14 shows the known deposits in the U.S. of these forms of aluminum ore superimposed on a map giving the yearly average direct solar insolation.

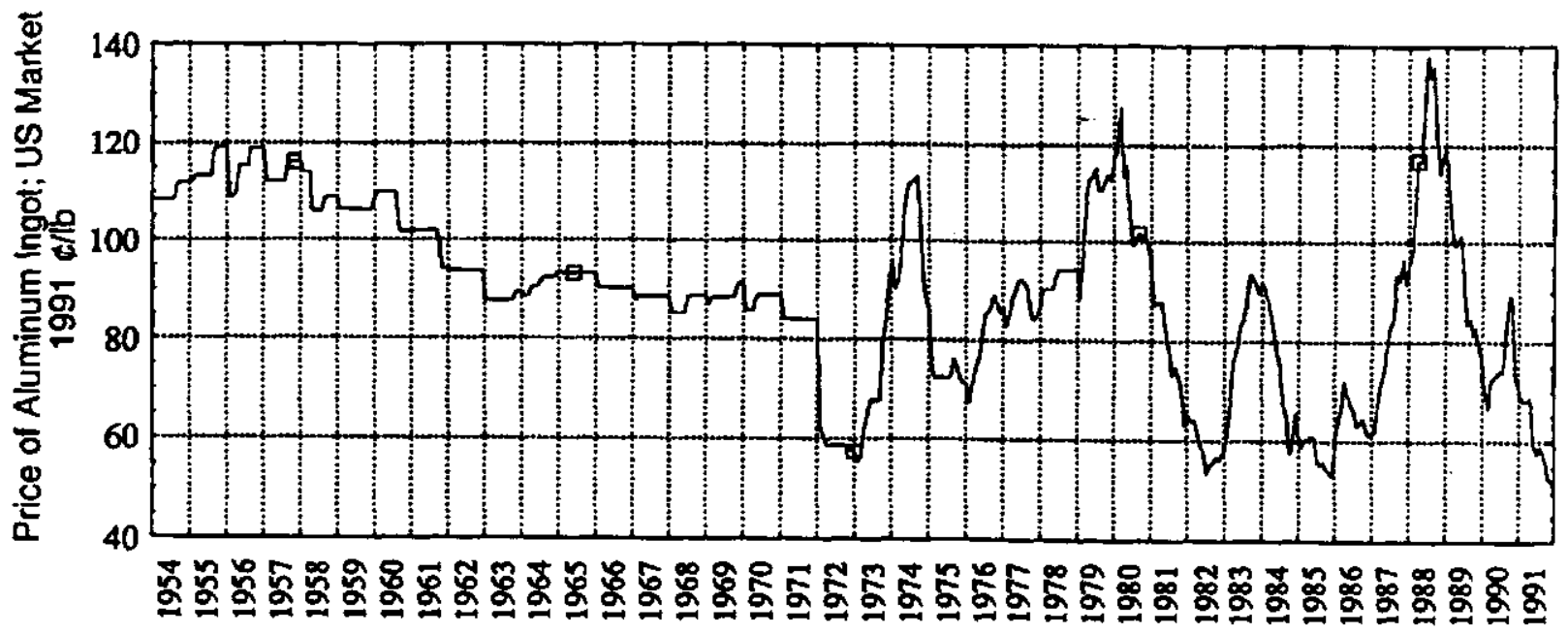

Fig. 13. Price of aluminum ingot in the US market for the years 1954-1991 expressed as 1991S. Data from Metals Week and Chemical Engineering. The values for 1954-1990 have been adjusted to $1991 \$$ using the Marshall and Swift index for these years (Chemical Engineering, various year-end issues).

\begin{tabular}{|c|c|c|}
\hline Source & Formula & $\begin{array}{l}\mathrm{Mass}_{2} \\
\mathrm{Al}_{2} \mathrm{O}_{3} \\
\end{array}$ \\
\hline Bauxito & & $65-85$ \\
\hline $\begin{array}{c}\text { Boehmite } \\
\text { Diaspore } \\
\text { Gibbsite }\end{array}$ & $\begin{array}{l}\mathrm{Al}_{2} \mathrm{O}_{3} \cdot \mathrm{H}_{2} \mathrm{O} \\
\mathrm{Al}_{2} \mathrm{O}_{3} \cdot \mathrm{H}_{2} \mathrm{O} \\
\mathrm{Al}_{2} \mathrm{O}_{3} \cdot 3 \mathrm{H}_{2} \mathrm{O}\end{array}$ & $\begin{array}{l}85 \\
85 \\
65\end{array}$ \\
\hline $\begin{array}{l}\text { Kaolin clay } \\
\text { Anorthosite }\end{array}$ & & $20-40^{40}$ \\
\hline $\begin{array}{r}\text { Abito } \\
\text { Anorthite }\end{array}$ & $\begin{array}{l}\mathrm{Na}_{2} \mathrm{O} \mathrm{Al}_{2} \mathrm{O}_{3} \cdot 6 \mathrm{SiO}_{2} \\
\mathrm{CaO} \cdot \mathrm{Al}_{2} \mathrm{O}_{3} \cdot 2 \mathrm{SiO}_{2}\end{array}$ & $\begin{array}{l}20 \\
37\end{array}$ \\
\hline $\begin{array}{l}\text { Coal thy ash } \\
\text { Coal Waste/Shales } \\
\text { Alunite }\end{array}$ & $\mathrm{K}_{2} \mathrm{SO}_{4} \cdot \mathrm{Al}_{2}\left(\mathrm{SO}_{4}\right)_{3} \cdot 4 \mathrm{Al}(\mathrm{OH})_{3}$ & $\begin{array}{l}30 \\
28 \\
37\end{array}$ \\
\hline
\end{tabular}

Table 2. Composition of other aluminum-containing ores on a mass percent basis. 


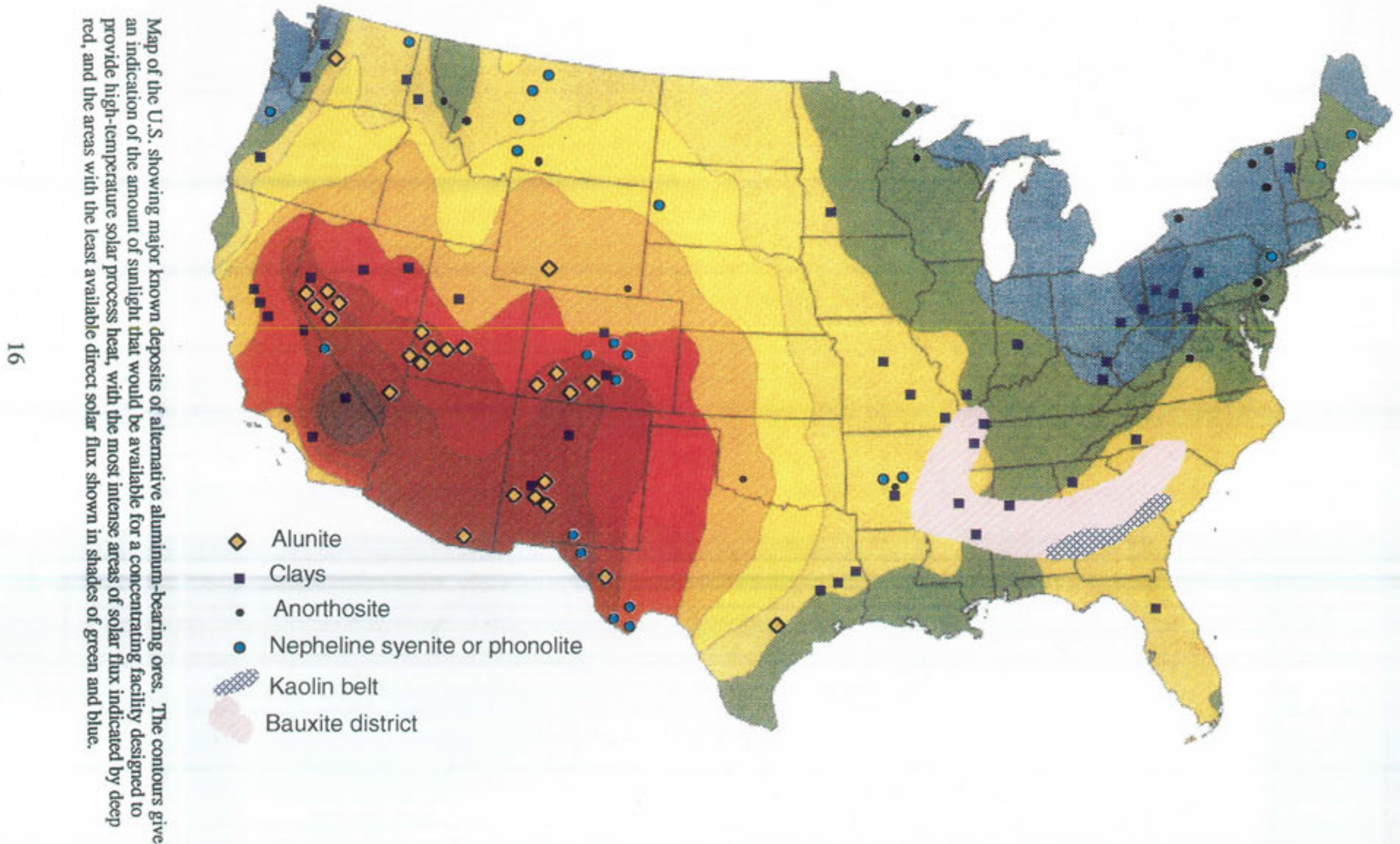




\section{4) Development of a more environmentally friendly process}

Among environmental regulations watched closely by the aluminum industry, the growing concem about global warming involves the industry on two of its emissions; $\mathrm{CO}_{2}$ and polyfluorinated carbon compounds. $\mathrm{CO}_{2}$ is released directly from the electrolysis process, and from the fossil-fuel electricity generating stations supplying electricity for the Hall-Héroult process. When the combustion of the consumable anodes alone is considered, the manufacture of aluminum releases $22 \mathrm{~kg}$ of $\mathrm{CO}_{2}$ per $\mathrm{kg}$ aluminum. The residence times of the $\mathrm{CF}_{4}$ and $\mathrm{C}_{2} \mathrm{~F}_{6}$ emitted are estimated to be of the order of 10 millenia, resulting in an equivalent global warming equivalent to $15-20 \mathrm{~kg} \mathrm{CO} 2$ per $\mathrm{kg}$ aluminum.

The possibility of a general carbon tax on $\mathrm{CO}_{2}$ emissions could have the most serious impact, increasing the cost of aluminum production by about $\$ 100$ per metric ton.(Morton, 1992) Regulation of emissions of fluoride compounds from the Hall-Héroult process are incorporated in the new provisions of the Clean Air Act, and the possibility of eliminating them is one strong motivation behind the search for inert electrode materials. This is a goal strongly supported by DOE research at all three major aluminum companies. The development of viable inert cathodes would represent only a partial reduction in $\mathrm{CO}_{2}$ emissions over what might be possible with a non-Hall-Héroult-based process.

Although the aluminum industry worldwide relies on hydropower for most of its process electricity, there is evidence that this pattern may be changing. As the costs and availability of hydropower have fluctuated, more smelters in the Pacific Northwest are turning toward naturalgas generated electricity supplied by pipelines from Canada. New Smelters have been constructed in the Middle East, a location that offers cheap and abundant natural gas. Policy experts within the Northem Power Planning Council with whom I have spoken pointed out that all of the good hydropower sites in the Pacific Northwest have been used, and there exists a real possibility that some older dams may not be relicensed.

\section{Unique Opportunities for Solar Energy}

\section{1) Solar Energy is a Unique Source of Process Heat}

Highly concentrated sunlight is capable of supplying process heat for chemical reactions at very high temperatures. On an industrial scale, thermal energy at temperatures up to about $1500 \mathrm{~K}$ have been generated for direct use in gas turbines. A preliminary set of calculations indicates that the size of a solar facility for aluminum processing would be within the range of sizes already built or analyzed for electric generating facilities. Pitman and Vant-Hull, for example, analyzed the performance of a two-aperture receiver receiving energy from a field of heliostats. Temperatures predicted in their model are in the range needed for aluminum reduction. Higher temperatures (and less energy) are routinely produced for experimental work, and we feel confident that an industrial-scale process could be developed to run at temperatures in the $1500-2500 \mathrm{~K}$ range. It is extremely difficult to add process energy at these temperatures from any other source: solar energy is unique in this respect. The only other sources are electric arc, combustion using pure $\mathrm{O}_{2}$, or the thermal energy from nuclear reactions. If electricity generated by combustion is used, only about $1 / 3$ of the energy contained in the fuel is available. If the fuel is burned directly, then it must be bumed in pure oxygen to reach $2000 \mathrm{~K}$, and even then, very little energy is available at these temperatures to supply process heat. Only concentrated solar energy and nuclear fission energy are candidates for supplying process heat at these high temperatures.

2) The Solar Advantage: fixed costs; steady supply

As mentioned in the section on why industry should be interested in an alternative process, it is not only the high cost of electricity that is making the U.S. lose its international competitiveness. Risk is imposed by fluctuating costs and fear of increasing energy costs. Here, use of solar energy as process heat may well have an advantage. The investment in a solar concentrating facility for electricity generation is frequently not competitive with other fuel sources of energy because it entails such a large initial capital cost. This may be thought of by 
considering the costs for a coal generating plant if it was forced to buyall of the coal it would consume in its lifetime. This capital cost may not be as important a factor when considered alongside the advantage an aluminum company would derive from knowing that the energy for its process would be constant, basically covered in the amortization of the plant capital costs.

\section{3) Drastic Reduction of $\mathrm{CO}_{2}$ Emissions}

Use of high-temperature solar process heat will drastically reduce $\mathrm{CO}_{2}$ emissions from the aluminum industry, with the release tied only to the stoichiometric amount of carbon needed for the process rather than being tied to either the fuel used to generate electricity $(*$ as in the case of natural-gas or coal generated electricity) or to the $\mathrm{CO}_{2}$ released in the Hall-Heroult process. The gas product from the process will be $\mathrm{CO}$ rather than $\mathrm{CO}_{2}$; if desired, a water-gas shift reactor could recover $\mathrm{H}_{2}$ from the process. 
Fig. 15. Processes that end with the production of alumina.

\begin{tabular}{|c|c|c|c|c|c|c|c|}
\hline Sinter Processes: & Pederson Process & Haglund Process & Serpek/AIN Process & $\begin{array}{l}\text { AlCOA } \\
\text { "Dry Process" }\end{array}$ & $\begin{array}{l}\text { Ammonium Sulfate } \\
\text { Process }\end{array}$ & $\begin{array}{l}\text { Acid* } \\
\text { Treatments } \\
\text { Knollin Clays }\end{array}$ & $\begin{array}{l}\text { H+ process } \\
\text { shales } \\
\text { coal-rejects }\end{array}$ \\
\hline $\begin{array}{l}\text { Co-produces } \\
\text { cement }\end{array}$ & $\begin{array}{l}\text { Co-produces } \\
\text { cement\&plg Iron }\end{array}$ & $\begin{array}{l}\text { Co-produces } \\
\text { FeSI alloy and } \\
\mathrm{H}_{2} \text { as } \mathrm{H}_{2} \mathrm{~S}\end{array}$ & Co-produces $\mathrm{NH}_{3}$ & & $\begin{array}{l}\text { Co-produces } \\
\text { fertllizer compounds; } \\
\text { potash sulfuric acid }\end{array}$ & 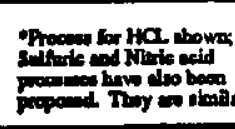 & athontly \\
\hline
\end{tabular}

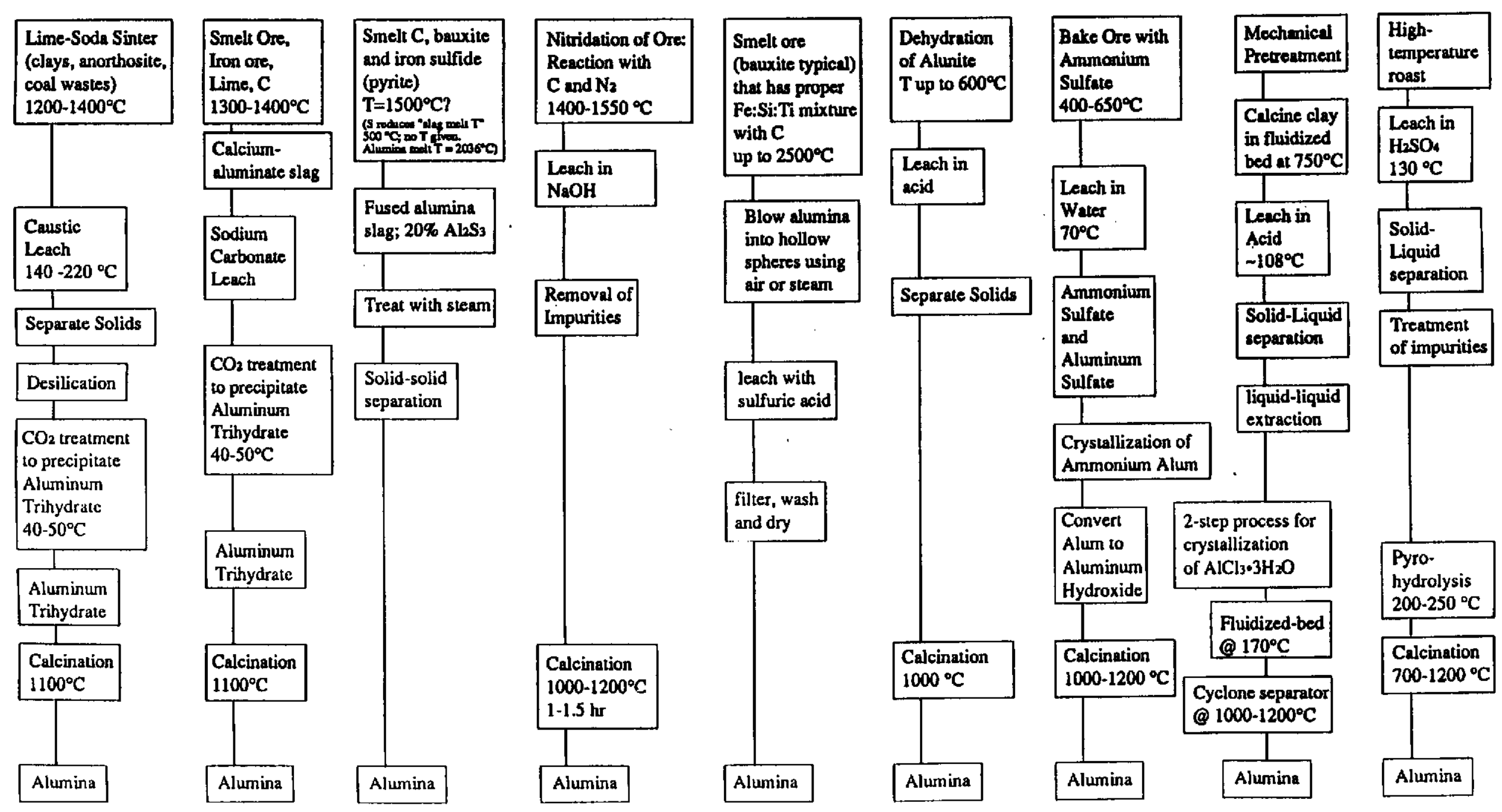




\section{Review of the known processes for aluminum production}

Many of the processes proposed to replace the Bayer process have been implemented to the pilot-scale level. During WWII, the Bureau of Mines supported a number of research projects around the country in a national defense effort to find and develop domestic, nonbauxite sources for aluminum ore. A mini-plant was operated through the 50's at least in Laramie Wyoming to gain operating experience with the most promising of these processes. The research literature extends will back into the mid-1800's, when the main challenge seemed to be the difficult problem of removing the silica without losing alumina in the various ores. Key information on the thermal portions of these processes has been summarized in fig. 15 . Alternative Ore Processes-End product $\mathrm{Al}_{2} \mathrm{O}_{3}$

In many processes, an initial step in ore preparation is a relatively high-temperature $\left(900^{\circ} \mathrm{C}\right)$ roasting of the ore to change its handling properties. This is especially important in processes that use clays, but an initial thermal step may also be used to increase the solubility of the alumina and perhaps decrease that of the impurities for acid processes, or to pre-reduce some of the impurities, especially the silica. Most processes end with a calcination step carried out at $1000-1200^{\circ} \mathrm{C}$ to drive off the water bound to the alumina and produce a crystalline form of alumina. One other very interesting approach used to convert the alumina in anorthosites to a soluble form was to melt the ore at temperatures near $1700^{\circ} \mathrm{C}$, and rapidly cool it by dropping it into water, onto steel plates or blowing it into fibers using steam jets ( Leitch, 1965; Iverson, 1967). These steps appear to be excellent, and rather straightforward candidates for the use of high-temperature solar process heat. Other portions of these alumina extraction processes require lower-temperature process heat easily supplied from a solar-heated standard transfer fluid such as high-pressure steam. I have not covered the details of the chemistry of the wet portions of these processes, nor have I given a complete description of the high-temperature portions of most of them. Excellent chemical reviews appear in Edwards (Edwards, 1930), Pearson (Pearson, 1955), and any handbook on Inorganic Chemistry. This figure is mostly useful as a tool in organizing and presenting the processes I discuss, but is no substitute for a detailed chemical process flowsheet. The temperatures I have given are sometimes the result of good guessing on my part, since chemistry reviews don't seem to be as concemed with giving this information, and some of it comes from patents that are so old that the measurements of temperatures are approximate at best. I have noted important co-products for processes that might add value where they are known to me; conversely, I have not even begun to indicate those that are negative products.

In the summary presented here I have separated the alumina extraction processes into two types. The strategy of the "chemical methods" attempt to extract the alumina in aqueous solution, aiming to form a pure aluminum salt solution while leaving as many of the impurities insoluble. Their thermal requirements are typically less demanding; they might begin with a high-temperature ore pre-treatment step, and end with a high-temperature alumina dehydration step, but the main challenges are in the costs, recovery and process variables of the various chemical steps involved. The "dry processes" proceed with a different strategy, attempting to reduce the impurities to a metallic state, then separate them from the molten alumina slag. They are typically carried out almost entirely at high temperatures, and though blast-furnace operations have been developed for many, an electric furnace is more typically used for these processes.

\section{Reduction/Reaction Dry Processes that primarily replace the Bayer Process to give $\mathrm{Al}_{2} \mathrm{O}_{3}$}

\section{Sinter-leaching processes}

Alumina may be extracted from anorthosite, clays and coal wastes via lime and lime-soda sinter processes. These are high-temperature dry processes that rely on the reaction of the alumina with lime and or soda to produce soluble sodium or calcium aluminates. Cement is a co-product, and is important in making these processes competitive. Several aluminum companies experimented with and abandoned versions of this process early in the century; Alcoa ran a commercial plant in Badin, N.C. from 1925-1928, later opening a plant in Arvida, Canada. 
The U.S. Bureau of Mines researched sinter processes to extract alumina from non-bauxitic ores starting from WWII and continuing at least into the 80's in a national program to find domestic sources for aluminum manufacture(Cservenyak, 1947; Lundquist, 1963; Henn, 1969; Peters, 1967; Eisele, 1979). Parallel efforts appeared in Canada(Archibald, 1944). Articles on these processes have appeared more recently as interest in using coal waste and fly ash for alumina manufacture has grown(Padilla, 1982\&1983; Goodboy, 1976). The reaction between alumina and soda occurs at about $900^{\circ} \mathrm{C}$, but the process is operated at higher temperatures, up to about. $1300^{\circ} \mathrm{C}$, to give a more easily handled product. The impurities in the ore also combine with the soda to form silicates, ferrates and titanates. Lime is generally added to minimize soda loss to these compounds. The process has generally been conducted in an electric furnace.

\section{Pedersen Process}

The Pedersen process has been in operation since 1928 at the Høyanger plant of the Norsk Aluminium Co. Its original purpose was to produce a low-sulfur pig iron, but later the process was adapted to use the high-iron/low-silica bauxite that came to Norway from Greece and France. A mixture of bauxite, limestone with a low $\mathrm{MgO}$ content, coke and iron ore is smelted in an electric furnace at temperatures around $1300-1400^{\circ} \mathrm{C}$. Alcoa, in cooperation with the US Bureau of Mines, developed a blast furnace for the process (Edwards, 1930). Pig iron and a calcium aluminate-calcium silicate slag are recovered, and the slag is leached in hot sodium carbonate-caustic solution to form soluble sodium aluminate and insoluble calcium carbonate.

\section{Alcoa "Dry Process"}

This process was originally investigated by Hall, but he could not purify the alumina well enough to use it in the electrolysis cells. Alcoa solved these problems, and operated a commercial process for some years. A mixture of Fe and Si-containing bauxites, with a proper mixture of $\mathrm{Si}, \mathrm{Fe}$ and $\mathrm{Ti}$ is dehydrated at probably around $1000^{\circ} \mathrm{C}$. It is then smelted in an electric furnace with carbon to reduce all of the impurities and some of the alumina. A layer of pure molten alumina forms which floats above a layer of molten Fe-Si-Al-Ti alloy. The top layer is poured off at about $2500^{\circ} \mathrm{C}$, and the alloy is tapped out on the side of the furnace. As the alumina is poured off it can be blown into small hollow spheres with a jet of superheated steam or air. This step also helps oxidize any remaining $\mathrm{Fe}$, remaining $\mathrm{C}$ and dissolved carbides. To improve the purity of the alumina, an acid leach step may be added.(Edwards, 1930)

\section{Haglund Process}

The Haglund process is a modification of the Alcoa dry process. It has been in operation at Maghera, Italy from 1929-1936, and at the Vereinigte Aluminium Werke (VAW) plant in Lauta, Germany. The key modification this process introduces is the lowering of the melting point of the ore by at least $500^{\circ} \mathrm{C}$ through the presence of sulfur. In this process, iron sulfide (pyrite) is included with the bauxite and coke furnace charge. The resulting alumina appears as conundum. The process could also be used to produce $\mathrm{Al}_{2} \mathrm{~S}_{3}$ for a subsequent disproportionation reaction producing $\mathrm{Al}$.

\section{Serpek AIN Process}

One of the more interesting dry processes was patented and researched early in the century primarily as a route to ammonia. With the development of the Haber process, the Serpek process became less economical and work seems to have ceased on its development. It might be an interesting process for a solar cycle if ammonia is also a desired product. The first step, which is highly endothermic, is the production of aluminum nitride. This can be carried out at 1350 $1600^{\circ} \mathrm{C}$ via a reaction between $\mathrm{C}$, flowing $\mathrm{N}_{2}$ and the $\mathrm{Al}_{2} \mathrm{O}_{3}$ (Sohn, 1986; Murray, 1994\&1995). The leach step in $\mathrm{NaOH}$ produces $\mathrm{NH}_{3}$, which can also be produced by reacting the AlN with steam or water at about $600^{\circ} \mathrm{C}$. The final step is the calcination step at $1000-1200^{\circ} \mathrm{C}$ to produce $\mathrm{Al}_{2} \mathrm{O}_{3}$ (Pearson, 1955; Edwards, 1930; Serpek patents; 1907-1917). 


\section{Chemical (wet) processes to replace the Bayer process to give $\mathrm{Al}_{2} \mathrm{O}_{3}$}

\section{Kalunite process and ammonium sulfate process}

The Kalunite process, which relies on the co-production of fertilizer and sulfuric acid to make it economical, was commercialized in Marysville, Utah in the early 40's (?) and in the 70's in southwestem Utah (Walker, 1974; Fleischer, 1944). The process would be applicable to any aluminous raw material that could be converted to potassium alum. Temperatures required in the process are moderate, ranging from about $600^{\circ} \mathrm{C}$ for the initial dehydration to $1000^{\circ} \mathrm{C}$ for the final calcination.

The ammonium sulfate process is similar thermally to the Kalunite process, with a first step at $450-650^{\circ} \mathrm{C}$ and a final calcination step at $1000-1200^{\circ} \mathrm{C}$ (St.Clair, 1944).

\section{Acid Processes and the $H+$ process}

The main thermal demand for each of these processes appears to be in the final calcination step, carried out at temperatures around $1000^{\circ} \mathrm{C}$. The $\mathrm{H}+$ process was commercial in France by the Pechiney company(Michelet, 1979). Investigations into acid processes in this country were performed under the Bureau of Mines, beginning with the efforts during WWII to find domestic sources for aluminum manufacture. There is an enormous literature covering details and variants of such processes; I have not even begun to review it. Several review articles have also been published(Nunn, 1979; Peters, 1967; Bengtson, 1979). When clay is the feedstock for the process, a pre treatment step carried out at $750^{\circ} \mathrm{C}$ appears to solve problems that occur with the solutions turning to cement or slime. The acid operations are generally carried out at temperatures from $100-250^{\circ} \mathrm{C}$. A final calcination step is carried out at 1000 $1200^{\circ} \mathrm{C}$. 
Fig. 16. Summary of the processes that end with the production of al.uminum

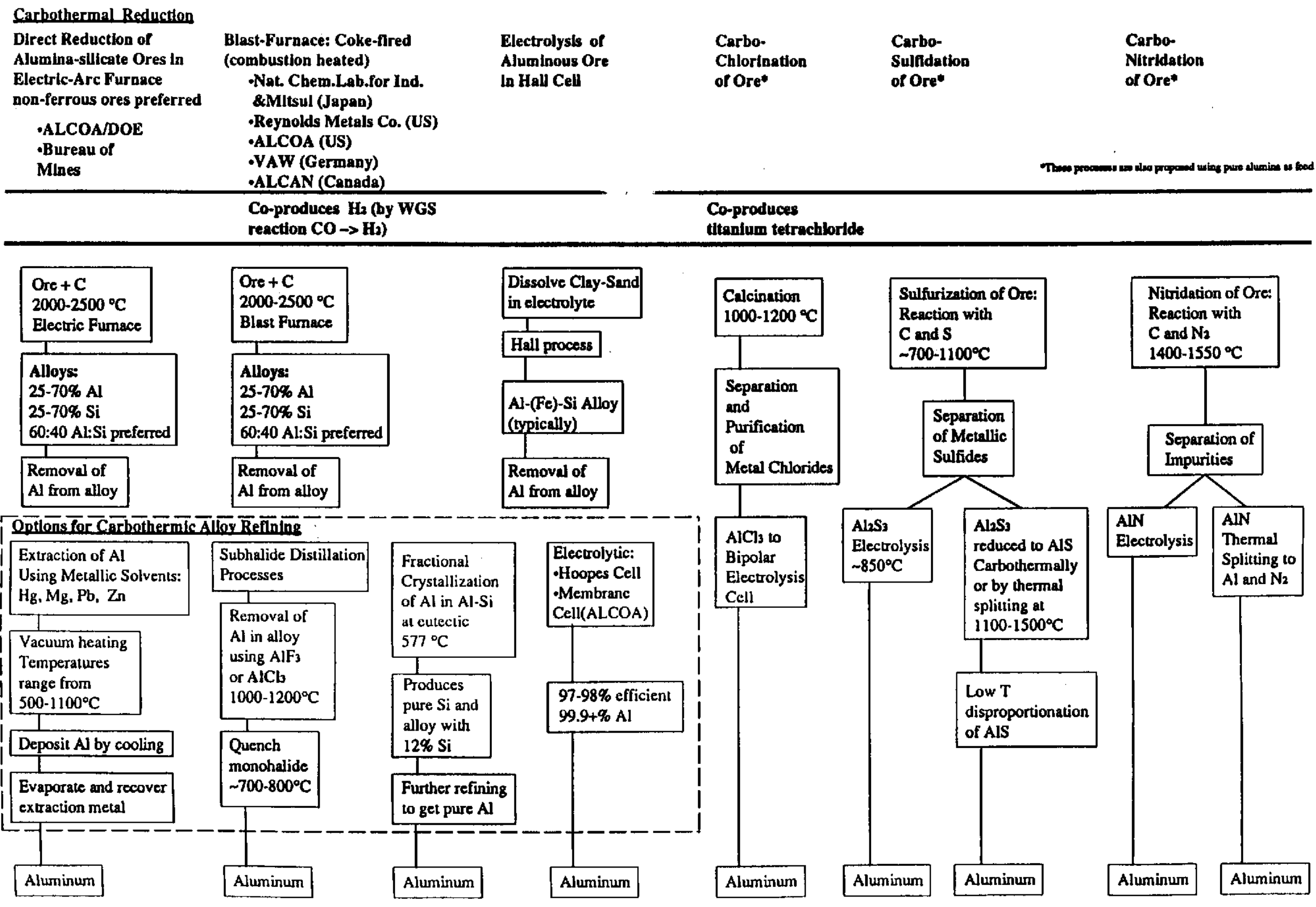


Alternative Processes-End product Aluminum or Aluminum Alloy

Key thermal aspects of alternative processes that begin either with alumina or a form of ore and end with pure aluminum or an aluminum alloy are summarized in fig. 16.

\section{Direct Thermal Processes to produce Aluminum}

From my literature survey and talks with researchers at Alcoa, Reynolds and Kaiser, it seems that the major aluminum companies that were working on research into direct reduction thermal processes to make aluminum in a conventional electric smelting or combustion-heated furnace have gradually abandoned the idea. More details are given in Appendix A. Their work has turned now to investigations of a process that might take place in a molten carbideoxycarbide mixture, or to the production of an intermediate compound, or to the production of an aluminum alloy that could be further refined to the needed purity. The best reviews of early carbothermal processes were written by P.T. Stroup (1964), Pearson (1955) and Edwards (1930).

At the end of the 1950's and beginning of the 1960's there was renewed research into carbothermal routes to aluminum. The reactors and processes proposed were electrothermal, though Alcoa has a patent that shows ä conceptual process heated by a nuclear reactor (Cochran, 1976). Four aluminum companies (Alcoa, Alcan, Pechiney-Ugine and Reynolds) and Japan did large-scale testing.

\section{Alcoa, direct reduction to aluminum}

In the 50's, Alcoa was awanded a patent for a direct method of producing aluminum in an electric furnace (Miller, 1958; Motzfeldt, 1989). Details of the process, such as the configuration of the reactor, are not given, but the temperatures appear to have been in the range 1900-

$2100^{\circ} \mathrm{C}$. A carbon-containing molten aluminum phase floated above a molten oxycarbide layer, but on cooling the carbon deposited as $\mathrm{Al}_{4} \mathrm{C}_{3}$. This could be separated from the molten aluminum with a fluxing agent (chlorine or aluminum chloride), and the metal was equal in quality to electrolytically produced aluminum. Difficulties would be expected in separating the fluxing agent for recycle

\section{Reynolds, \& Alcan: multi-stage reduction to aluminum}

Reynolds has performed investigations into direct carbothermal processes for many years. Some of their proposals combine an electrothermal and combustion heated process. In one of the more interesting processes proposed, a 3-stage process, Stage I would be a shaft-furnace partly electrically heated and partly C(coke)-combustion heated to produce an Fe-Ti-Si alloy and a pure aluminum oxycarbide melt. $\mathrm{CO}$ generated by the $\mathrm{C}$ combustion and the reaction would be recovered for burning in a coal-power plant to generate the electricity required for the process.

Some of the alloy metals would be contained in the oxycarbide melt; they would be removed in Stage II by bringing the melt into contact with some of the Al formed. Stage III consists in a preliminary decarbonization treatment of the oxycarbide melt prior to purification with a fluxing agent, as in the Alcoa process. The Alcan process is similar except that they do not seem to have a decarb step; they apparently treat the entire oxycarbide melt with the fluxing agent.

Reynolds also holds a series of patents that address the main difficulties of the direct carbothermal process; the problem of producing a product with less than $20-30 \% \mathrm{Al}_{4} \mathrm{C}_{3}$, and the problem of excess loss to vaporization. The heat rate delivered to the reduction zone is of critical importance; too much energy flux and the products vaporize, blowing holes through the overlaying materials, too low a flux and the reaction zone is too cold to produce the desired products. The kinetics of the reduction reactions determine the heat rate. A continuous submerged electric arc delivers too high a heat rate to the reduction zone, thus Reynolds process patents specify a pulsed or moving arc to limit the vaporization ${ }^{\dagger}$.

\section{Direct Reduction of Ore to produce an Al-Si-Fe-Ti-Mn alloy}

It is possible to carbothermically reduce the ore to produce an aluminum alloy. The strategy of the processes that produce an alloy of aluminum is to decrease the amount of aluminum lost as a vapor by alloying it with another metal, then to separate it later by a refining 
step. There are a number of thermal processes that were used on a commercial scale early in the history of the aluminum industry. Table 3 summarizes the direct reduction processes that result in an alloy of aluminum that had been researched up to about 1961 according to Stroup (1964) and amended by Motzfeldt (1989). Some of these may have merit now, especially if many of the technical difficulties that made them uneconomical have been solved. I have not had time to evaluate them in the detail required. My review section here focuses more on the processes researched in the later years (40's-80's). I am also very intrigued by processes that were implemented by Germany during WWII; many were technologically innovative though not competitive with the conventional processes. Many were developed to a commercial scale in post WWI and WWII Germany because the economics weren't the deciding factor.

\begin{tabular}{|llcc:c|}
\hline \multicolumn{1}{|c}{ Company } & \multicolumn{1}{c}{ Location } & $\begin{array}{c}\text { Starting } \\
\text { Year }\end{array}$ & Alloy & $\begin{array}{c}\text { Maximum } \\
\text { production }\end{array}$ \\
\hline Cowles & Lockpon, NY & 1886 & $15 \mathrm{Al}-85 \mathrm{Cu}$ & $150 \mathrm{~kg}$ Alday \\
Cowles & Mllton, England & 1886 & $15 \mathrm{Al}-85 \mathrm{Cu}$ & $100 \mathrm{~kg}$ Alday \\
ALCOA & Badin, NC & 1924 & $35 \mathrm{Al}-65 \mathrm{Cu}$ & 500 ton/year \\
ALCOA & Badin, NC & 1928 & $30 \mathrm{Al}-70 \mathrm{Si}$ & 1000 ton total \\
Metallgesellschaft & Horrem, Germany & 1926 & $60 \mathrm{Al}-40 \mathrm{Si}$ & 10,000 ton/year \\
VAW & Lauta, Germany & 1936 & Converted to Si & 2000 ton/year \\
VAW & Pocking, Germany & 1942 & $60 \mathrm{Al}-40 \mathrm{Si}$ & 16,000 ton/year \\
Bureau of Mines & Albany, OR & 1951 & $40 \mathrm{Al}-60 \mathrm{Si}$ & Experimental \\
Natl. Met. Corp & Springfield, OR & 1954 & Converted to Si & 3600 ton/year \\
TVA & Wilson Dam,AL & 1947 & $50 \mathrm{Al}-50 \mathrm{Si}$ & Experimental \\
USSR-State & Dnepr, USSR & 1937 & $30 \mathrm{Al}-70 \mathrm{Si}$ & 1000 tonyear \\
Pechiney & Nogueres, France & 1961 & Al-Al4C3 & 4000 tonlyear \\
ALCAN & Arvida, Canada & 1961 & Al-Fe-Si & 7000 ton/year \\
\hline
\end{tabular}

Table 3. From Stroup (1964) and Motzfeldt (1989): A summary of the large-scale experiments and commercial processes used for the production of aluminum alloys by a direct thermal (carbothermal) process.

\section{Carbon Reduction to produce Copper-Aluminum Alloy}

This is one of the earliest attempts to produce aluminum, developed in 1885 by Cowies. Alumina was smelted in an electric furnace with coke and copper, forming an alloy consisting of 10-20\% Al that was used as copper bronze. Clay could be substituted for the pure alumina, resulting in a $\mathrm{Cu}-\mathrm{Si}-\mathrm{Al}$ bronze. Attempts to make pure aluminum in the furnace were a failure because the product was aluminum carbide rather than the metal. Another approach was to make an alloy of aluminum with tin, zinc, copper or silver, and then to extract the alloying metal with mercury, resulting in a fairly pure aluminum. With tin as the alloying metal, lead was used for the extraction. The Hoopes electrolytic process could refine the aluminum, resulting in an ultrapure aluminum. The process is still used today to produce $99.99+\% \mathrm{Al}$.

Kuwahara/Mitsui/National Chemical Laboratory for Industry

The Japanese aluminum industry has not been competitive on the world market since 1973 due to the high energy prices in Japan. The country must now import the majority of its aluminum. A reseanch project initiated in this climate was given the status "National Project", with $2 / 3$ of its financing from the government. Most of the processes developed aimed to produce an Al-Si alloy, the group project in Omuta proposed to do subsequent cooling and purification using molten lead. That project has been ended(Kuwahara, patent 1983, Motzfeldt, 1989). Work in developing a blast-furnace process was continued by another group in Tsukuba; they did not recover significant amounts of pure $\mathrm{Al}$, but found an $\mathrm{Al}-\mathrm{Si}-\mathrm{Fe}$ alloy with 20-30 mass 
percent $\mathrm{Al}$ in their reactor. Material losses were large; $40-70 \%$ of the aluminum from the bauxite was lost as dust or evaporated(Dokiya, 1983 \& 1986; Yokokawa, 1985; Motzfeldt, 1989).

\section{Alcan Monochloride processing of Carbothermically-produced Alloy}

Alcan developed and commercialized a process in Arvida, Canada, based on reversible reactions in the $\mathrm{Cl}-\mathrm{Al}$ system that extracted $\mathrm{Al}$ from the impure alloy whose main component was aluminum and allowed recovery of the metal through back reaction and condensation. Patented by Gross in 1949, it was based on the reversible reaction $2 \mathrm{Al}+\mathrm{AlCl} 3 \longrightarrow 3 \mathrm{AlCl}$, and was referred to as the monochloride process. The reaction to form $\mathrm{AlCl}$ is endothermic at 1000 $1400^{\circ} \mathrm{C}$, and is reversible at a lower temperature, $700-800^{\circ} \mathrm{C}$. Crushed aluminum-containing alloy was heated to $1200^{\circ} \mathrm{C}$ with $\mathrm{AlCl}_{3}$ in an endothermic reaction and the resulting mixture cooled and condensed to recover aluminum. The aluminum was recovered in the liquid state, and the $\mathrm{AlCl}_{3}$ recirculated. The process was complex; a technical success, but an economic failure according to a company chemist(McGeer, 1986). The main difficulties were the production of environmentally unacceptable, stable chloride compounds that required treatment, and the problem of finding materials to withstand the corrosive chlorides.

\section{AlcoalDOE/Bureau of Mines}

The Bureau of Mines supported considerable research from the 40's through the 50's into processes that would use nonbauxite ores to produce aluminum. Several successful projects were scaled up to large experimental/small pilot plant size. Alcoa and DOE collaborated to investigate the feasibility of a blast-furnace process to produce Al-Si alloys that would be refined in a membrane-separated electrolysis cell Alcoa had under development. The investigation began in the late 1970's, and ended in 1983 with the publication of several extensive final reports(Bruno, 1983; Troup, 1983) and more condensed presentations at the AIME 1983 Annual Meeting(presented 1983; papers published 1984; Bruno, 1984; Troup, 1984; Stevenson, 1984). Three process concepts were evaluated in the program: a combustion-heated blast furnace, a combination blast-arc furnace, and a submerged arc fumace. The laboratory experiments simulating a combustion-heated blast furnace were carried out in an induction-heated electric furnace swept with an appropriate volumetric flow of $\mathrm{CO}$ gas. No aluminum was recovered in this process because the high flowrate of $\mathrm{CO}$ from the hot combustion zone greatly increased the formation of $\mathrm{Al}, \mathrm{Al}_{2} \mathrm{O}$ and $\mathrm{SiO}$ vapors from the hot reaction zone. These products were carried to the outlet, where they solidified causing formation of a bridge and plugging the outlet. Iron was added, which made the process feasible, but the removal of iron from an Al-Si alloy is extremely difficult, and the electrolysis cell Alcoa wanted to use would not work with an ironcontaining alloy. Alloys $\mathrm{FeSiAl}_{4}$ and $\mathrm{FeSi}_{2} \mathrm{Al} 5$ form, resulting in the loss of significant amounts of $\mathrm{Al}$ for each percent Fe present. Work ended on this process in 1980 (Troup, 1980).

To overcome these two problems (reflux with the $\mathrm{CO}$; bridging), a combined electriccombustion heated process was developed. This strategy was developed mainly as a way of decreasing the electricity use compared to an all-electric heated submerged-arc process while lowering the combustion $\mathrm{CO}$ flow rate so that the desired chemical reactions would occur. This is a problem that would not be encountered in a solar-heated process, where the $\mathrm{CO}$ in the system would be only that evolved from the reduction reactions.

Previous studies had indicated that the reduction reactions in the $\mathrm{Al}_{2} \mathrm{O}_{3}-\mathrm{SiO}_{2}$ system occurred in three stages. The reduction of the $\mathrm{SiO}_{2}$ to $\mathrm{SiC}$ is virtually complete at $1550^{\circ} \mathrm{C}$, oxycarbide slag formation occurs between $1900-1950^{\circ} \mathrm{C}$, and metal production occurs between $2000-2050^{\circ} \mathrm{C}$. The temperature needed for the SiC production step was to be supplied with combustion, and the final two steps would be electrically heated. This solved the problem of the $\mathrm{CO}$ gas from the combustion process removing the $\mathrm{Al}, \mathrm{Al}_{2} \mathrm{O}$ and $\mathrm{SiO}$ vapors at higher temperatures, which was the main reason the combustion-heated blast furnace process failed. Unfortunately, the kinetics of the $\mathrm{SiO}_{2}$ reduction step were too slow below $1500^{\circ} \mathrm{C}$, and at higher temperatures $\mathrm{Al}_{2} \mathrm{O}_{3}$ reduction begins to occur, so the Alcoa group concluded that a series-type process involving a pre-reduction of $\mathrm{SiO}_{2}$ using combustion heat followed by an electricallyheated process was impractical. (Stevenson, 1984) 
A pilot-scale submerged arc furnace was operated successfully to evaluate the potential of carbothermic reduction of a mixed-oxide one to an Al-Si alloy. The furnace operated at around $2000^{\circ} \mathrm{C}$, producing an $\mathrm{Al}-\mathrm{Si}$ alloy containing $30-40 \% \mathrm{Si}$, and smaller amounts of $\mathrm{Fe}$ and $\mathrm{Ti}$. This alloy was purified to commercial-grade aluminum in a two-step process beginning with a 2-stage fractional crystallization at $590^{\circ} \mathrm{C}$, the eutectic point for $\mathrm{Al}-\mathrm{Si}$. The resulting alloy, 12.6 (eutectic) to $17 \% \mathrm{Si}$, was refined in an electrolytic diaphragm cell. This process is similar in principle to the Hoopes process, developed in the first part of the century in cooperation with Alcoa, to refine carbothermically produced alloys. The introduction of the porous diaphragm allows even closer anode-cathode spacing, and results in a minimum power consumption. The diaphragm cell consumes $5.5 \mathrm{kWh} / \mathrm{kg} \mathrm{Al}$ produced, compared to $13.2-17.6$ for the Hall-Héroult cell(Bruno, 1984). A cell for a pilot plant was apparently designed and built, but never used since the results from the blast-furnace research were so poor that the project was ended in 1983 (Bruno, 1983). The cell requires substantial thermal energy to keep it at its operating temperature; another straightforward application for solar process heat. Thermal process to form an intermediate, followed by electrolysis

I believe some of these procēsses may have a good potential for using solar process heat. The temperatures required to produce the intermediate compound typically are not as high as with the direct reduction processes. One process, the Toth process, is not reviewed here at all. It may be familiar to the reader since it apparently received considerable publicity and numerous patents were issued, but the reviews written by industry chemists that I read were unanimous that the process was flawed to the point that it would not operate as claimed(see, e.g., McGeer, 1986 and Motzfeldt, 1989).

\section{Carbochlorination of Ore/separation and purification of metal chlorides/Bipolar Cell}

Alcoa operated a pilot commercial plant based on the carbochlorination of alumina, followed by an electrolysis that used non-consumable electrodes in a bipolar cell. Chlorine was produced at the anode to be recycled to the initial carbochlorination step. The main advantage of the process came from the increased volumetric productivity of the bipolar cells, resulting in lower capital costs (Cochran, 1987). The chief difficulties were encountered in corrosion of the materials of construction for the chlorination step, the production of stable chloride compounds needing treatment., and the fact that it used a gaseous feed $\left(\mathrm{Cl}_{2}\right)$ and produced a gaseous product $\left(\mathrm{AlCl}_{3}\right)$. This may not be a disadvantage for a solar process since considerable experience has accumulated in reactor design and optimization for gaseous streams.

Chlorination of the raw aluminous ore could have an economic advantage over the alumina-based process. Titanium tetrachloride, a precursor to the manufacture of $\mathrm{TiO}_{2}$, is the most valuable co-product, and can apparently be fairly easily separated (Cochran, 1987). The chief diseconomies come from the fact that both reactants and products are gaseous, and compared to the Bayer process, higher temperatures are required.

Carbonitridation or sulfidation of OrelElectrolysis of $\mathrm{AlN}$ or $\mathrm{Al}_{2} \mathrm{~S}_{3}$

It may be possible to electrolyze $\mathrm{AlN}$ or $\mathrm{Al}_{2} \mathrm{~S}_{3}$ in a bipolar cell using non-consumable electrodes. A significant advantage over an aluminum chloride-based cell would be that a much lower theoretical voltage would be required, fig. $6 \mathrm{~b}$. Industrial chemists seem to have fairly strong negative impressions of any sulfur-based commercial process (see, for example, McGeer, 1986, p153), and studies are mentioned but dismissed. Side reactions occurring both in the sulfidation step and in the electrolysis cells are mentioned as problems, but research continues in this field (Loutfy, 1979). There are some advantages to the sulfur-based route over a chlorinebased one. The products appear in the condensed phase, so reactor volume would be less. The sulfur is $5 X$ cheaper than chlorine, and sulfur losses to the impurities in the ore would be less. A thermal route, similar to the Alcan monochloride process, is available to produce aluminum from $\mathrm{Al}_{2} \mathrm{~S}_{3}$. AlS is stable at high temperatures, but below $1010^{\circ} \mathrm{C}, \mathrm{AlS}$ decomposes to form $\mathrm{Al}_{2} \mathrm{~S}_{3}$ (s) and $\mathrm{Al}$ (l) by the reaction

$$
3 \mathrm{AlS}(\mathrm{s}) \rightarrow \mathrm{Al}_{2} \mathrm{~S}_{3}(\mathrm{~s})+\mathrm{Al} \text { (l). }
$$


The process to form AlN requires higher temperatures than the sulfidization process. Various temperatures are cited in the literature. My experience was that AlN could be formed in a carbothermal process at atmospheric pressure at temperatures of $1400-1550^{\circ} \mathrm{C}$; this agrees with the earlier work by Sohn and Harbuck (Sohn, 1986; Murray, 1994). It is desirable to minimize the temperature used: higher temperatures result in very stable forms of AN that are difficult to dissolve. Some research appears to have been done to find appropriate electrolytes for an AlN electrolysis process (Bonomi, 1982), with more work cited from researchers in the former USSR on the problem. There is some hope that a bipolar cell with inert electrodes could be developed for this process. I don't know how one would separate the $\mathrm{Si}_{3} \mathrm{~N}_{4}$ and possibly $\mathrm{SiC}_{\text {produced }}$ from the $\mathrm{Al}_{2} \mathrm{O}_{3}-\mathrm{SiO}_{2}$ containing ore, so $\mathrm{Al}_{2} \mathrm{O}_{3}$ may be the most appropriate starting point for an AlN electrolysis process.

Electrolysis of Aluminous Ore in Hall Cell; production of Al-Si alloy

Hall also worked to develop a process that might use an unrefined ore in an electrolysis cell. In theory, it should be possible through a multi-staged electrolysis to separate the metal components of an ore in sequence $\mathrm{Fe}, \mathrm{Si}, \mathrm{Ti}, \mathrm{Al}, \mathrm{Mg}$ through $\mathrm{Ca}$. Unfortunately, the depositions of these metals overlap because they form alloys and other compounds. The Si content in the cell causes a loss in current efficiency proportional to its concentration in the melt. The Al-Si metal produced can be refined through electrolytic or thermal processes, as discussed earlier.

\section{Identifying Processes with the Best Potential for Solar Process Heat}

It is not entirely the goal of this project to identify the most thermodynamically elegant aluminum extraction process for further study as a candidate for solar-thermal process heat. While the distribution of energy usage in a process is of interest (ie, the chemical thermodynamics), an equally important consideration is to identify a process that has been substantially researched but that failed economically because of the necessity to add hightemperature process heat from electric sources, or has failed technically due to the nature of the process heat added. This is an area in which high-temperature solar process heat is unique: it is available at temperatures far above any that can be reached through combustion heating.

Almost all alternative processes have a thermal component, thus all might be viewed as candidates for solar process heat addition. Once a high-temperature facility is constructed, other processes might be carried out economically using excess capacity or other waste heat. Much of the Bayer Process, for example, could be carried out with a high-temperature, solar heated heat transfer fluid as an adjunct to a solar-heated direct reduction process. In choosing potential solar applications I looked for.

for which

1) well-researched processes and thus

2) the use of solar process heat might solve problems previously encountered,

3) the use of high-temperature solar energy could be the critical economic and technical factor in their success or failure.

The first criterium meant that I did not consider in much depth emerging technologies such as plasma production of aluminum, or other processes that seem to have received mostly academic interest such as the sulfur routes to aluminum.

The second eliminated other processes that might well adapt well to solar process heat-an example might be the one generally known as the Alcoa Smelting Process, which has been implemented to the pilot stage and carried out commercially for some time before failing for other reasons that the implementation of solar process heat could not solve.

The third criterium required some subjective input-I looked in particular for processes that had to be conducted at such high temperatures that electric furnaces (or nuclear reactors) were the only option for implementation. 


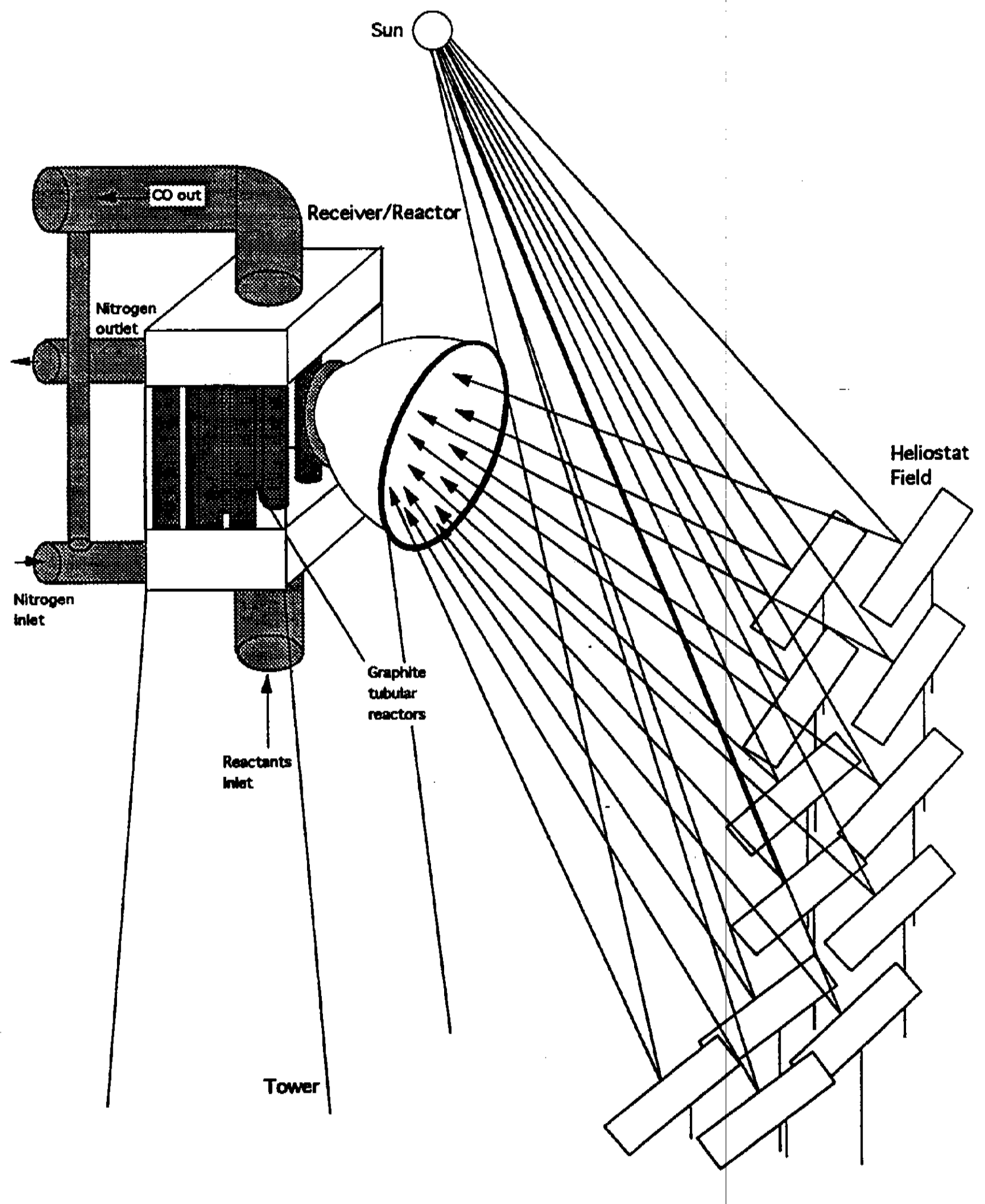

Fig. 17. An enginecr's sketchof a receiver and reactor designed for high-temperaure solar processing of aluminum. The receiver is shown as though its walls (and its insulation) had been removed to show banks of tubular reactors in which the process might be conducted. With graphite reactors the concentration of $\mathrm{O}_{2}$ surrounding the reactors must be kept low enough to suppress combustion-achievable by recirculating the CO-containing exhaust gas or with a mostly- $\mathrm{N}_{2}$ atmosphere. 
Desirable features for solar-thermochemical process

Other desirable process features come directly from my experience designing chemical reactors for solar process heat:

1) Process does not require tight temperature control for success- \pm 50 to $100^{\circ} \mathrm{C}$

2) Process can be condusted at atmospheric pressure

3) Control of reaction atmosphere not critical so that receiver/reactor may operate without a window.

4) Interruptible process is desirable-the consequmces of unscheduled shutdown are not dire

5) 24-hour operation not critical, or process has two or more steps, some of which might be performed at night.

Using these criteria for choosing among the many alternative aluminum extraction processes reviewed here, I believe three types of processes have the greatest potential for immediate success. The first is a reduction process to an Al-Si alloy along the lines of work that was done by Alcoa under a joint project with DOE in the late 70's and early '80's(Bruno, 1983). The second would be a direct carbothermal reduction process to aluminum along the lines described in Reynolds patents (Kibby, 1973,1976,1977,1980,1982,1983). Of future interest, a carbothermal process to make an AlN intermediate that could be electrolyzed more easily than $\mathrm{Al}_{2} \mathrm{O}_{3}$ using nonconsumable electrodes should be researched more fully.

\section{Conclusion}

Processes with excellent potential for high-temperature solar process heat Process \#1: Alcoa Al-Si alloy reduction process

Alcoa researched the production of an aluminum-silicon alloy suitable for further refining to pure aluminum or use directly as an alloy. Two of the most serious technical difficulties encountered could be solved through the use of solar process heat rather than coke-combustion heating. The process control requirements were modest, and the reactors used in bench/pilot studies could be easily adapted for solar process heat.

Problem \#1: Total reflux of products

The flow rate of $\mathrm{CO}$ would be much lower through a solar-heated reactor, thus the extreme problems with bridging and reflux of the product would be minimized with solar heat. Furthermore, the report from Alcoa mentions the potential technical and economic desirability of operating with a closed reactor, this should be more easily achieved with solar process heat than with an arc-type furnace design.

Problem \#2: high temperatures required for process attainable only with electric furnace

Temperatures in the range $2000-2100^{\circ} \mathrm{C}$ are required for reduction of $\mathrm{Al}_{2} \mathrm{O}_{3}$ and $\mathrm{SiO}_{2}$. The reactor design and external heating that proved successful in Alcoa's tests would not be too difficult to adapt to solar process heating. These temperatures were achieved in an inductively heated graphite tube reactor, and are within the range achievable with either a receiver/reactor mounted on central tower heated by a field of heliostats, or in a scaled-up solar-furnace facility. This method of adding process heat would be quite similar to a solar beated reactor with concentrated sunlight incident on the tube exterior. A sketch showing what a central tower facility equipped with a secondary concentrator might look like for this application appears in fig. 17.

Other process difficulties aided by the availability of solar process heat

The electrolytic separation of the Al and Si would also benefit from external heating of the electrolysis cell. This step of the process could be carried out at night (most likely, over the entire 24-hour period) so that 24-hour operation could be achieved. 
The main process question that would need to be addressed would be the effect of running a reactor only during daylight hours, or the possible benefits of running 24 hours with supplemental external heating from an electric source.

Process \#2: Reynolds Carbothermal Reduction

Kibby's patents describe several process and reactor concepts for carbothermal production of a low-carbide aluminum. I have included this as a candidate process despite its complexity and apparent need for fairly tight control.

Problem \#1: Control of heat rate critical

In my conversations with Kibby, he indicated the critical need to introduce process heat at exactly the correct heat rate to achieve a successful recovery of aluminum metal. Kibby felt that this might be an area for which solar heating could improve the process because it was nearly impossible to control the heat rate with an electric arc furnace.

Problem \#2: high temperatures required for process attainable only with electric furnace The use of solar process heat is also dictated by the temperatures required-in the range 2050$2150^{\circ} \mathrm{C}$.

As with the Alcoa process, it will be necessary to investigate whether the process can be successfully interrupted or whether auxiliary heating will be required. The main advantage of this process is that it, if it can be made to work, it results in substantially pure aluminum metal. No further electricity is required for the process. The main difficulty to be overcome are that the reactors described in Kibby's patents are complex, two-stage and two-temperature zone designs that would pose quite an engineering challenge to adapt for solar process heat. Each reaction zone or reactor also would appear to require fairly tight temperature control to achieve their full potential for producing low-carbide metal.

Process \#3: Carbothermal production of AlN Intermediate

It is possible to produce AlN carbothermally either from an impure ore or from pure alumina. For a process based on the former, two thermal steps would be needed to form the pure AlN required for electrolysis to aluminum metal, but both of these steps could be identical carbothermal reductions in a nitrogen atmosphere.

Problem \#2: high temperatures required for process attainable only with electric furnace

The temperatures required to produce $\mathrm{AlN}$ from a reaction between $\mathrm{Al}_{2} \mathrm{O}_{3}$ and $\mathrm{C}$ in $\mathrm{N}_{2}$ are lower than those required in the two direct reduction processes above-about $1350-1550^{\circ} \mathrm{C}$ is desirable. The process temperature appears to affect the crystal structure and thus the solubility of the AlN produced, so the lowest temperature consistent with the desired production rate is desirable. The comparatively low temperatures reduces and possibly eliminates the losses to volatile aluminum containing compounds. The temperatures are also low enough that carbides and oxycarbide formation is inhibited. The reaction seems to be very simple and does not suffer from the formation of complex and unwanted intermediates. It should be possible to use zirconia tubular reactors or other zirconia refractory material rather than graphite, thus making the maintenance of an inert protective atmosphere unnecessary.

The main drawback for this process is that it would no replace the use of electricity completely. The theoretical electrolysis potential for $\mathrm{AlN}$ is about $2 / 3$ that for $\mathrm{Al}_{2} \mathrm{O}_{3}$ per mole of Al produced, so the potential exists for significant electric savings. Some research has been done to find suitable electrolytes for an electrolytic reduction of AlN; this will need to be investigated further. 


\section{Appendix A}

\section{Interviews with Process Managers and Researchers at Alcoa, Kaiser and Reynolds}

\section{Alcoa}

I had long-term and fairly substantial, cooperative contact with senior research managers at both Alcoa and Reynolds. At Alcoa, my first point of contact was with R. Lee Troup, author of the section of Alcoa's final report on the failure of the direct-combustion heated reduction project. He indicated that there was no groundswell of interest currently in direct reduction processes that he was aware of, but that the pattern for technologies there was that they tended to remain dormant for long periods, then reemerge when problems had been solved. $\mathrm{He}$ recommended I speak with C. Norm Cochran, who continues to maintain his interest in carbothermal and direct reduction processes. His name is on many of the Alcoa carbothermal process patents. He retired from Alcoa about 7 years ago, after serving as their technology planner, but continues to consult actively on projects. He confirmed Troup's impressions that research into altemative processes was unfortunately a "dead issue" at Alcoa, with research into Hall process improvements dominating. He indicated that he had been working on the theoretical background for an altemative thermal process for which he could not divulge details, but which would have a very good potential for solar process heat. Some of its potential advantages included a good productivity per unit reactor volume, indicating the potential for achieving excellent economies of scale; no production of intermediates; no loss of aluminum to volatiles; complete recycle of alumina and the ability to operate as a batch and interruptible process if required. I then spoke with Marshall Bruno, the manager responsible for the AlcoaDOE research to make Al-Si via carbothermal reduction of ore. He also indicated that although there was not currently "a tremendous interest in alternative processes, it was not true that there was no interest". He mentioned that the new director (at the Technical Center? of Alcoa itself? I failed to record the details) had shown keen interest in direct reduction processes, though no action had come of it as yet. Marshall put the group from NREL in touch with several people within Alcoa, and also gave us the names of interested DOE administrators. I sent him a copy of the interim report from April.

\section{Reynolds}

At Reynolds, my first point of contact was with the Power Manager for the Pacific Northwest; Dan Ten Eyck. He immediately referred me to Alton Tabereaux, manager of theExtractive Metallurgical Technology department in the Manufacturing Technology Laboratory at Reynolds Metals Company in Alabama. He told me that although there had been intense interest and work to develop a viable direct carbothermal process in the 70's and 80's, that the company had already spent a great deal of money on this line of research and that the feeling was they were convinced that it wasn't possible. He indicated that carbothermal "has a bad name" at the lab; that his impression was that the chemistry was the main problem. He referred me, however, to Bob Kibby, a now-retired researcher whose name is on most of the Reynolds carbothermal process patents of the last 30 years. Though he retired 14 years ago, he continues to be enthusiastic about the feasibility of a carbothermal route to the manufacture of aluminum. I spoke with him at some length several times; he persuaded me to include the Reynolds carbothermal process that he researched in the list of candidates for solar thermal processes. His research addressed and solved two of the three main chemical-process complex problems with carbothermal, and he felt that the use of solar energy as process heat might solve the final difficulty of controlling the heat rate to control vaporization which could only be awkwardly solved when an electric arc was used as the heat source. He further recommended that I speak with Tony Saavedra, who continues in a research and managerial position at Reynolds, and who had worked closely with him on carbothermal reduction research. I did not have a chance to contact him. 
Kaiser

At Kaiser, my first point of contact was also with the Power Manager for the Pacific Northwest, who referred me to Steve Abernathy, Senior Process and Energy Applications Specialist. Here, the approach was somewhat different since I did not have any points of contact either from the patent literature or chemical research publications. I sent a brief (1 paragraph abstract) description of the potential for solar energy as chemical process heat, and an indication of my interest to speak with members of their process research group if they were interested further. Steve took this to a meeting of the group, where they apparently discussed it and decided that such work would be too large a reach for Kaiser, they had never supported extensive research into alternative processes in the history of the company, and there was currently no such research underway. They are researching process refinements and improvements, some of it DOE sponsored and probably similar to the other companies. Steve indicated that the plants the company owns in the Pacific Northwest are "old and paid-for"-50 years old-and that since Kaiser is vertically integrated there was no interest in processes to replace the Bayer-bauxite steps. This confirmed my impression of activity at Kaiser-I had not seen Kaiser patents in my search for example, a fact which could either be symptom of extreme corporate secrecy or inactivity in the field. 


\section{REFERENCES}

Review and General Background Articles and Books

J.C. Agarwal and J.R. Sinek, "The Energystics of Metal Production", Energy Use and

Conservation in the Metals Industry, ed. Y.Austin Chang, W.M. Danver, and J.M. Cigan, AIME, 1975, pp121-129.

C. N. Cochran, "Alternate Smelting Processes for Aluminum", Light Metals 1987, ed. R.D. Zabreznik, Warrendale, PA: TMS 1987, pp.429-443.

J.D. Edwards, F.C.Frary and Z. Jeffries, The Aluminum Industry: Aluminum and its Production, McGraw-Hill, New York, NY, 1930.

G. Gerard and P.T. Stroup, Extractive metallurgy of aluminum v. 1: Alumina, New York, Interscience Publishers 1963.

K. Grjotheim, C. Krohn, M Malinovsky, K. Matiasovsky, J. Thonstad, Aluminium electrolysis: Eundamentals of the Hall-Heroult process, Dusseldorf, Aluminium-Verlag, 1982.

K. Grjotheim, C. Krohn, M Malinovsky, K. Matiasovsky, J. Thonstad, Aluminium electrolysis: The Chemistry of the Hall-Heroult process, Dusseldorf, Aluminium-Verlag, 1982.

K. Grjotheim, B.J. Welch, Aluminium smelter technology:apure and applied approach, Dusseldorf, Aluminium-Verlag, 1980.

K. Grjotheim and B.J. Welch, "Impact of Altemative Processes for Aluminum Production on Energy Requirements", Journal of Metals, 33, no.9, 1981, pp26-32.

K. Grjotheim and J.B. See, "The Hall-Heroult Process and Alternative Processes for the Manufacture of Metallic Aluminium", Minerals Sci. Engng, 11, no.2, 1979, pp80-98.

N. Jarrett, "United States Extractive Metallurgy-the 80's and Beyond", The 1986 Extractive Metallurgy Lecture, Metallurgical Transactions B, 18B, June 1987, pp289-313.

N. Jarrett, "Hall-Héroult Process Developments", Extraction Metallurgy '81, IMM Symposium 21-23 September 1981, London, pp222-233.

N. Jarrett, "Aluminum Smelting: Past, Present, and Future Challenges", Tutorial Lectures in Electrochemical Engineering and Technology, R. Alkire and T. Beck, eds., AIChE Symposium Series, v77, no.204, AIChE, New York 1981.

J.P. McGeer, "Alternative Methods for the Production of Aluminum Metal", Proceedings of a conversazione on "The production of liquid alumimum" :presented on the occasion of the 100th anniversary of the Hall-Heroult process, The Metallurgical Society of the Canadian Institute of Mining and Metallurgy, Toronto, Ont. Aug 17-20 1986.

K. Motzfeldt, H. Kvande, A. Schei and K. Grjotheim, Carbothermal production of aluminium: chemistry and technology, Dusseldorf, Aluminium-Verlag, 1989.

T.G. Pearson, The Chemical Backeround of the Aluminum Industry, The Royal Institute of Chemistry, lectures, monographs and reports, 1955 No.3, London.

P.T. Stroup, "Carbothermic Smelting of Aluminum", The 1964 Extractive Metallurgy Lecture, Transactions of the Metallurgical Society of the AIME, 230, April 1964, pp356-372.

B.J. Welch, "Aluminum Reduction Technology-Entering the Second Century", Journal of Metals, 40, no.11 (1988), pp19-25.

J.B. Todd,"Energy Reduction in Hall-Heroult Cells with Conventional and Special Electrodes", Journal of Metals, 33, no.9 (1981), pp42-45. 
Processes that primarily replace the Bayer Process:

Review Articles

Anonymous, "The Production of Pure Alumina", The Mining Magazine, February, 1929, pp117. 121.

K.B. Bengtson, "A Technological Comparison of Six Processes for the Production of ReductionGrade Alumina from Non-bauxitic Raw Materials", Light Metals 1979, ed. W.S. Peterson, pp217-282.

M.K. Schad (Lurgi), "Concepts of Nuclear Heat Supply for Production of Aluminum Oxide and for Refineries", Energy-The International Journal, v16, no1/2 (1991), pp565-571.

H. Beisswenger and H.W. Schmidt, (Lurgi), "New Coal Based Alumina Plant Energy Concept", Light Metals 1984, ed. J.P. McGeer, Warrendale PA:TMS 1984, pp370.

D.J. Donaldson, "Energy Savings in the Bayer Process", Journal of Metals, v33 no.9 (1981), pp37-41.

Sinter Processes: Lime-Soda and Lime

F.R. Archibald and C.F. Jackson, "Alumina from Clay by the Lime Sinter Method", Transactions of the AIME, 159, Reduction and refining of nonferrous metals 1944, pp227-240.

R.L. Copson, J.H. Walthall, and T.P. Hignett, "Extraction of Alumina from Clays by the LimeSinter Modification of the Pedersen Process", Transactions of the AIME, 159, Reduction and refining of nonferrous metals 1944, pp241-254.

FJ. Cservenyak, "Recovery of Alumina from Kaolin by the Lime-soda Sinter Process," Bureau of Mines R.I.4069, 1947.

J.A. Eisele and D.J. Bauer, "Evaluation of Technology for the Recovery of Metallurgical-grade Alumina from Coal Ash", R.I. 8791, Bureau of Mines Reno, Nev. 1979.

K.P. Goodboy, "Investigation of a Sinter Process for Extraction of $\mathrm{Al}_{2} \mathrm{O}_{3}$ from Coal Wastes", Light Metals 1976, v.2, ed. S.R. Leavitt, Warrendale, PA:1976, pp19-28.

J.J. Henn, P.W. Johnson, E.B. AmeyIII, F.A.Peters, "Methods for Producing Alumina from Clay; an evaluation of two lime sinter processes", Bureau of Mines R.L7299, 1969.

R.V. Lundquist, "Recovery of Alumina from Anorthosite, San Gabriel Mountains, CA, using the lime-soda sinter process", Bureau of Mines R.I. 6288, 1963.

F.A. Peters, P.W. Johnson, J.J. Henn, R.C. Kirby, "Methods for Producing Alumina from Clay; an evaluation of a lime-soda sinter process," Bureau of Mines R. .6927, 1967.

R. Padilla and H.Y. Sohn, "Extraction of Alumina from Coal Wastes by the Lime-soda Sinter Process", Light Metals 1982, ed. J.E. Andersen, Warrendale, PA: 1982, pp81-94.

F.A. Peters, R.C. Kirby and K.B. Higbie, "Methods for Producing Alumina from Clay-an Evaluation", Journal of Metals v19, no10 (1967), pp26-34.

H+ Process

J. Cohen and H. Mercier, "Recovery of Alumina from Non-bauxite Aluminum-bearing Raw Materials", Light Metals 1976, v.2, ed. S.R. Leavitt, Warrendale, PA:1976, pp3-18. (Pechiney) J.M. Michelet, "Extraction of Alumina from Coal Bearing Shales: The H+Process", Rev. Metall. $M E S, 79$, nol, (1982) pp15-20. 
Alunite Processes

H.W. St.Clair, S.F. Ravitz, A.T. Sweet, C.E. Plummer, "The Ammonium Sulphate Process for production of Alumina from Western Clays", Transactions of the AIME, 159, Reduction and refining of nonferrous metals 1944, pp255-265.

A. Fleischer, "The Kalunite Process", Transactions of the AIME, 159, Reduction and refining of nonferrous metals 1944, pp267-279.

W.W. Walker, D.N. Stevens and Alumet tecnical staff, "The Earth Sciences-National-Southwire Alunite-to-Alumina Project", Light Metals 1974, vIII, ed. H. Forberg, Warrendale PA:TMS 1974, pp683-688.

Melt-Quench process for Anorthosite

H.G. Iverson, H. Leitch, "Extracting alumina from silicates by melting, quenching, and sulfuric acid leaching", Journal of Metals, 19, no.12, 1967, pp28-31.

H.Leitch, H.G. Iverson, J.B. Clemmer, "Extraction of alumina silicates by leaching melted and quenched anorthosite in sulfuric acid", Bureau of Mines R.I. 6744, 1965.

Acid Processes

R.F. Nunn and P. Chuberka, "Comparative Economicss of Producing Alumina from US Nonbauxitic Ores", Light Metals 1979,ed. W.S. Peterson, Warmedale, PS:TMS, 1979, pp283-334.

R.S. Olsen, "Feed Preparation and Leaching of Aluminum from Kaolinitic Clay with Hydrochloric Acid", Light Metals 1981, ed. G.M. Bell, Warrendale, PA:TMS, 1981, pp263-277.

F.A. Peters, R.C. Kirby and K.B. Higbie, "Methods for Producing Alumina from Clay-an Evaluation", Journal of Metals, 19, no.10, 1967, pp26-34.

E.P. Stambough and J.F. Miller, "Hydrothermal Precipitation of High Quality Inorganic Oxides", Light Metals 1983, ed. E.M. Adkins, Warrendale, PA:TMS, 1983, pp1145-1158.

S. Ziegenbalg and G. Haake, "Investigations into the Alumina Extraction from Clay by

Hydrochloric- and Sulphuric-Acid Leaching", Light Metals 1983, ed. E.M. Adkins, Warrendale, PA:TMS, 1983, pp1119-1143.

Processes that Replace the Hall-Héroult Process to make Aluminum:

Direct Thermal Processes for Aluminum Production

M. Dokiya, M. Fujishige, T. Kameyama, H. Yokokawa, "Aluminum Blast Furnace", Light Metals 1983, ed. E.M. Adkins, Warrendale, PA:TMS, 1983, pp651-670.

M. Dokiya, M. Fujishige, H. Yokokawa, "Blast Furnace Process for Aluminum, Calcium Carbide, Calcium Hydride and Titanium", Light Metals 1986, ed. R.E. Miller, Warrendale, PA: TMS, 1986, pp241-246.

C.N. Cochran, "Calculated Equilibrium for Carbothermic Reduction of Alumina", Metal-GasSlag Reactions and Processes, Z.A. Foroulis,and W.W. Smeltzer, eds., the Electrochemical Society, Princeton N.J., 1975, pp299-316.

T. Kikuchi, S. Ochiai, T. Kurosawa, T. Yagihashi, "Carbothermic Reduction of Alumina and Aluminous Ores and Effects of Several Additional Materials", Transactions of the Japanese Institute of Metals, 12, 1971, pp55-61.

T. Kikuchi, S. Ochiai, T. Kurosawa, T. Yagihashi, "Carbothermic Reduction of Bauxite and Colloidal Earth by Girod and Heroult Furnaces", Transactions of the Japanese Institute of Metals, 12, 1971, pp62-67.

R.M. Kibby and A.F. Saavedra, "Model Studies in Carbothermic Reduction of Alumina", Light Metals 1987, ed. R.D. Zabreznik, Warrendale, PA: TMS 1987, pp.263-268. 
K. Motzfeldt and B. Sandberg, "Chemical Investigations Concerning Carbothermic Reduction of Alumina", Light Metals 1979, ed. W.S. Peterson, Warrendale, PA: TMS 1979, pp411-428.

A.F. Saavedra and C.L. Compton, "Analytical Methods for Determination of Slasg and Metal Composition in Carbothermic Production of Aluminum", Light Metals 1986, ed. R.E. Miller, Warrendale, PA: TMS, 1986,pp247-252.

A.F. Saavedra and R.M. Kibby, "Investigating the Viability of Carbothermic Alumina Reduction", Journal of Metals, v.40, No.11, 1988.

H. Yokokawa, M. Fujishige, S. Ujiie, M. Dokiya, "Phase Relations Associated with the Aluminum Blast Furnace: Aluminum Oxycarbide Melts and Al-C-X (X=Fe, Si) Liquid Alloys", Metallurgical Transactions B, Vol 18B, June 1987, p433-444.

S. Ujiie, S. Hirose, M. Fijishige, H. Yokokawa, M. Dokiya, "Reduction Behavior of Alumina in Pure Oxygen Blast Furnace for Aluminum Production", Transactions of the Japan Institute of Metals, 29, No.7 (1988), pp589-597.

H. Yokokawa, M. Fujishige, S. Ujiie, "Chemical Thermodynamic Considerations of Aluminum Blast Furnace", Light Metals 1985, ed. H.O. Bohner, Warrendale, PA: TMS, 1985, pp507-517.

Production of Al-Si Alloy

L.H. Banning, W.F. Hergert, "Experimental Production of Al-Si Alloys in a Three-Phase Fumace", Journal of Metals, v. 7 no. 5, 1955, pp 630-633.

M.J. Bruno, "Production of Aluminum-Silicon Alloy and Ferrosilicon and Commercial Purity Aluminum by the Direct Reduction Process", CONS-5089-16 UC-95f, Feb 1983, 466 pp. Appendix to the same: CONS-5089-16-App. 200 pp.

M.J. Bruno, "Overview of ALCOA Direct Reduction Process Technology", Light Metals 1984, ed. J.P. McGeer, Warrendale, PA:TMS, 1984, pp1571-1590.

O.C. Fursman and L.H. Banning, "Experimental Smelting of Aluminum Silicates to Produce Aluminum-Silicon Alloys", Bureau of Mines R.I. 5575, 1959.

E.L. Singleton, R. L. de Beauchamp, and T.A. Sullivan, "Recovery of Aluminum from Aluminum-Silicon Alloys", Bureau of Mines R.I. 7603, 1972.

D.T. Stevenson, "Feasibility of an Aluminum-Silicon Blast-arc Process", Light Metals 1984, ed. J.P. McGeer, Warrendale, PA:TMS, 1984, pp1613-1631.

M.M. Striplin, W.M. Kelly, "Aluminum-Silicon Alloys by Electrothermal Reduction of Clay with Coke", Chemical Engineering Progress, v43, no10, 1947, pp569-578.

R.L. Troup, "Special Technical Report: Technical Feasibility of Combustion-Heated Process for Producing Aluminum-Silicon Alloys", CONS-5089-9 UC-95f, 1980.

R.L. Troup, "Feasibility of an Aluminum-Silicon Blast Furnace", Light Metals 1984, ed. J.P. McGeer, Warrendale, PA:TMS, 1984, pp 1591-1612.

Production of Intermediate Al-compound

R.O. Loutfy, R.Keller, G.M. Cook, "Preliminary Thermodynamic Assessment of Processes to Produce Aluminum Using Aluminum Sulfide as an Intermediate Produce", ANL/OEPM-78-5, Argonne National Laboratory 1979.

N.Q. Minh, N.P.Yao, "The Electrolysis of Aluminum Sulfide in Molten Fluorides", Light Metals 1983, ed. E.M. Adkins, Warrendale, PA:TMS, 1983, pp 643-670.

N.Q. Minh, N.P.Yao, "The Electrolysis of Aluminum Sulfide in Molten Chlorides", Light Metals 1982, ed. J.E. Andersen, Warrendale, PA:TMS, 1982, pp 267-277. 
J. P. Murray and A. Steinfeld, "Solar Thermal Production of Nitrides by Carbothermal Reduction of Metal Oxides in a Nitrogen Atmosphere", Proc. ASME International Solar Energy Conference, San Francisco, USA, pp 59-66, (March 27-30, 1994).

J. P. Murray, A. Steinfeld and E.A. Fletcher, "Metals, Nitrides and Carbides via Solarcarbothermal reduction of Metal Oxides", Energy-The International Journal, v20, no.7. pp696704 (1995).

H.Y. Sohn and D.D. Harbuck, "Alumina from Coal Wastes through the Formation of Aluminum Nirride by Carbothermal Reduction under Nitrogen", Ind.Eng.Chem.ProdRes.Dev., 25, 1986, pp 367-372.

A. Bonomi, M. Hadate, F. Breda, C. Gentaz, "Exploratory Studies on Electrolysis of AlN Dissolved in Molten Salts", Journal of the Electrochemical Society, 129, no. 1, pp 102-106.

\section{Al-Cl Processes}

L. Burgess, "Separation of Eluminum, Berylllium, and Zirconium from their Ores", Transactions of the American Electrochemical Society, v XLVII, 1925, pp317-325.

Editorial Staff,"Alcan pilots $2400^{\circ} \mathrm{F}$ process equipment", Canadian Chemical Processing, 51, no.2, 1967, pp45-48.

P. Gross, "The Subhalide Distillation of Aluminium", International Congress on Aluminium, Paris 14-19 June, 1954, pp167-171.

S.S. Guzman and G.C. D'Andrea, "Thermodynamics of Alumina Chlorination", Light Metals 1987, ed. R.D. Zabreznik, Warrendale, PS:TMS 1987, pp417-427.

D.J. Milne and L.J. Wibberley, "Chlorination of Alumina and Bauxite using Pyrolytic Carbon as Reductant", Light Metals 1978, v.2, ed. J.J. Miller, Warrendale, PA:TMS, 1978, pp147-162.

E. Miller, G.E. Call, P.R. Haskett, and L.J. Nicks, "Fluidized-bed Decomposition of Aluminum Chloride Hexahydrate", Light Metals 1983, ed. E.M. Adkins, Warrendale, PA:TMS, 1983, pp253-271.

A.S. Russell, "Pitfalls and Pleasures in New Process Development", the 1981 Extractive Metallurgy Lecture, The Metallurgical Society of AIME, Metallurgical Transactions B, 12B, June 1981, pp203-215.

E.L. Singleton, D.E. Kirby and T.A. Sullivan, "Electrowinning Aluminum from Aluminum Chloride: Operation of a Two-Compartment Cell", R.I. 7212, U.S. Bureau of Mines, 1968.

E.L. Singleton, D.E. Kirby and T.A. Sullivan, "Electrowinning Aluminum from Aluminum Chloride: Operation of a Single-Compartment Cell", R.I. 7353, U.S. Bureau of Mines, 1968

\section{Aluminum Purification Processes}

W.C. Aitkenhead, Review of Recent German Developments in Auminum Refining", FIAT Final Report 907, 5 March 1947,

E. Bonnier, "Électrolyse des Aluminates", Congrès International de L'aluminium", Paris 1954.

H.W. St. Clair and D.D. Blue, "Recovery of Aluminum from Crude Aluminum-Silicon Alloy by Extraction with Moletn Zinc", Bureau of Mines R.I. 4535, 1949.

F.C. Frary, "The Electrolytic Refining of Aluminum', Transactions of the American Electrochemical Society, v XLVII, 1925, pp275-286.

W.J. Howell, C.A. Eckert, and R.N. Anderson, "Carbothermic Reduction Using Liquid Metal Solvents", Journal of Metals, V40, no 7., 1988, pp21-23. 


\section{Economic/Market factors}

R.G. Adams, "U.S. and World Energy Outlook-Implications foir the Aluminum Industry", Journal of Metals, v33 no.6 (1981), p141-144.

B. Barham, S.G. Bunker and D. O'Heran, States, Firms and Raw Materials the World Ecology of Aluminum, University of Wisconsin Press, Madison, Wisconsin, 1994.

S.C. Manaktala, "The Primary Aluminum Industry in the Commonwealth of Independent StatesPart 1", Journal of Metals, v44 no11 (1992), pp38-40.

D. Morton, "Today's Aluminum Industry: Facing the Economic and Environmental Challenges", Journal of Metals, v44 no. 11 (1992), p6.

OECD, Industrial Adaptation in the Primary Aluminum Industry, Paris, 1976.

OECD, Aluminum industry: energy aspects of structural change, Paris, 1983.

M. Peck, ed. The World Aluminum Industry in a Changing Energy Era, Resources for the Future, Washington D.C., 1988.

S.R. Spector, "Price and Availability of Energy in the Aluminum Industry", Journal of Metals, v33 no.6 (1981), p138-139.

J.A. Stuckey, Vertical Integration and Joint Ventures in the Aluminum Industry, Harvard University Press, Cambridge, Massachusetts, 1983.

U.S. Industrial Outlook 1994, 35th Annual Edition, U.S. Department of Commerce/International Trade Administration.

\section{Patents $\dagger$}

\section{ALN Process}

$1,030,929(1912)$

Process of Manufacturing Aluminium Nitrid

O.Serpek (Société generale des Nitrures)

$1,060,509$ (1913)

Process for the Manufacture of Aluminium Nitrid

O.Serpek (Société generale des Nitrures)

$1,155,840$ (1915)

Process of Fixing Nitrogen

O.Serpek (Société generale des Nitrures)

$1,180,840$ (1916)

Process of Producing Aluminium Nitrid

G Guilini

$1,196,639$ (1916)

Process of Fixation of Nitrogen

A. Badin (Société generale des Nitrures)

$1,198,965$ (1916)

T This list does not come from a complete review of the patent literature. This is a personal "short list" of patents I acquired because they seemed to be either technically interesting or might contain sketches of reactors that could be adapted for solar process. Two good books contain discussions of many of the patents listed here-Motzfeldt's "Carbothermic Production of Aluminum" covers carbothermic methods patented from 1968 through 1987. Edwards, Frary, and Jeffries book "The Aluminum Industry" lists and discusses many of the earty patents (through 1930). 
Process for Fixing Nitrogen by Means of Ferro-Aluminium or other ferro alloys O.Serpek (Société generale des Nitrures)

$1,305,414$ (1919)

Process and Apparatus for the Production of Metallic Nitrids

F.T. Snyder

$1,311,568$ (1919)

Process and Apparatus for Ptoducing Nitrogen Compounds, Especially Nitrids

A.R. Lindblad

$1,350,149$ (1920)

Process of Producing Nitrid of Aluminium from materiuals containing aluminic oxid

V. Gerber

$1,366,720(1921)$

M.C.J. Elisée de Loisy

Process and Plant for Industrially Carrying out Chemical Reactions in an Artificial Atmosphere

3,032,398 (1962)

Process and Fumace for the Continuous Production of Aluminum Nitride

J. Clair (Pechiney)

\section{Carbothermic Processes}

2,843,475 (1958)

Method of Producing Aluminum

P. Weiss (VAW)

4,099,959 (1978)

Process for the Production of Aluminum

E.W. Dewing, J.P. Huni, R.R. Sood and F.W.Southam(Alcan)

4,213,599 (1978)

Apparatus for the Production of Aluminum

E.W. Dewing, J.P. Huni, R.R. Sood and F.W.Southam(Alcan)

$4,314,846$ (1982)

Method for Carbothermic Production of Aluminum

K. Motzfeldt

4.394,167 (1983)

Method of Carbothermically Producing AluminumU.S. Patent

K. Kuwahara, (Mitsui Aluminum)

Reynolds Carbothermic Process

3,257,199 (1966)

Thermal Reduction

W. Schmidt (Reynolds)

3,254,988 (1966)

Thermal Reduction

W. Schmidt and G.P. Koch(Reynolds)

3,758,290 (1973)

Carbothermic Production of Aluminum

R.M. Kibby (Reynolds)

$3,975,187$ (1976) 
Treatment of Carbothermically Produced Aluminum

R.M. Kibby (Reynolds)

4,033,757 (1977)

Carbothermic Reduction Process

R.M. Kibby (Reynolds)

$4,216,010$ (1980)

Aluminum Purification System

R.M. Kibby (Reynolds)

4,334,917 (1982)

Carbothermic Reduction Furnace

R.M. Kibby (Reynolds)

$4,419,126(1983)$

Aluminum Purification System

R.M. Kibby (Reynolds)

Alcoa Carbothermic Process

2,829,961 (1958)

Producing Aluminum

M.A. Miller, L.M. Foster, and C.D. Baker (Alcoa)

3,971,653 (1976)

Carbothermic Production of Aluminum

C.N. Cochran (Alcoa)

4,046,558 (1977)

Method for the Production of Aluminum-Silicon Alloys

S.K. Das and R.A. Milito (Alcoa)

$4,053,303$ (1977)

Method of Carbothermically Producing Aluminum-Silicon Alloys

C.N. Cochran, S.K. Das, and R.A. Milito (Alcoa)

Alcoa Electrolytic Refining Process

1,534,031 (1925)

Electrolytic Production of Aluminum

F.C. Frary (Alcoa)

$1,534,316(1925)$

Production of Metallic Aluminum from Impure Materials

W. Hoopes, F.C. Frary and J.D. Edwards (Alcoa)

$1,534,317$ (1925)

Electrolytic Production of Aluminum

W. Hoopes, F.C. Frary and J.D. Edwards (Alcoa)

$1,534,318(1925)$

Electrolytic Refining of Aluminum

W. Hoopes, F.C. Frary and J.D. Edwards (Alcoa)

$1,534,319$ (1925)

Refining Aluminum Electrolytically with Fused Electrolytes

W. Hoopes, F.C. Frary (Alcoa) 


\section{Other Processes}

$1,569,483$ (1926) RE 17,001 (1928)

Process of Treating Ores Containing a Refractory Oxide

T.R. Haglund

1,618,105 (1927)

Process of Manufacturing Amuminum Hydroxide

H. Pedersen (Alcoa)

2,090,451 (1937)

Manufacture of Aluminium

O. Kruh

2,470,305 (1949)

Process for the Production and Refining of Aluminium

P. Gross

2,470,306 (1949)

Process for the Production and Refining of Metals

P. Gross

3.615,359 (1971)

Process for Producing Aluminum

C. Toth (Applied Aluminum Research Corporation)

$3,615,360$ (1971)

Process for the Continuous Production of Aluminum

H.G. Harris, R.V. Bailey, C. Toth (Applied Aluminum Research Corporation)

3,661,561 (1972)

Method of Making Aluminum-Silicon Alloys

F.W. Frey, D.O. Hutchinson, K.K. Seth (Ethyl Corporation)

3,661,562 (1972)

Reactor and Method of Making Aluminum-Silicon Alloys

K.K. Seth, C.W. Lanier (Ethyl Corporation)

3,853,541 (1974)

Method for Producing Aluminum Metal Directly from Ore

D.F. Othmer 


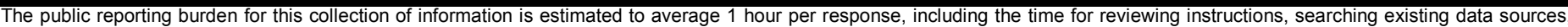

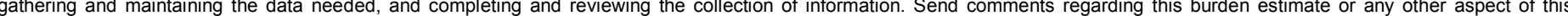

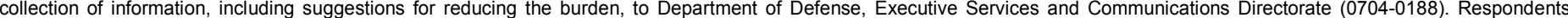

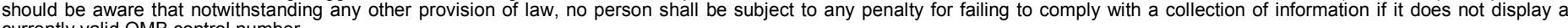
currently valid OMB control number.

PLEASE DO NOT RETURN YOUR FORM TO THE ABOVE ORGANIZATION.

\section{REPORT DATE (DD-MM-YYYY) May 2006 \\ 2. REPORT TYPE \\ Subcontract Report}

4. TITLE AND SUBTITLE

Investigation of Opportunities for High-Temperature Solar Energy in the Aluminum Industry
56

\section{AUTHOR(S) \\ J. Murray}
5a. CONTRACT NUMBER
DE-AC36-99-G010337

5b. GRANT NUMBER
3. DATES COVERED (From - To) August 1995

\section{5c. PROGRAM ELEMENT NUMBER}

5d. PROJECT NUMBER

NREL/SR-550-39819

5e. TASK NUMBER

WW1F.1000

5f. WORK UNIT NUMBER
7. PERFORMING ORGANIZATION NAME(S) AND ADDRESS(ES)

Department of Mechanical Engineering

Portland State University

Portland, Oregon

9. SPONSORING/MONITORING AGENCY NAME(S) AND ADDRESS(ES)

National Renewable Energy Laboratory

1617 Cole Blvd.

Golden, CO 80401-3393
8. PERFORMING ORGANIZATION REPORT NUMBER

XCK-5-15114-00

10. SPONSOR/MONITOR'S ACRONYM(S) NREL

11. SPONSORING/MONITORING AGENCY REPORT NUMBER NREL/SR-550-39819

\section{DISTRIBUTION AVAILABILITY STATEMENT}

National Technical Information Service

U.S. Department of Commerce

5285 Port Royal Road

Springfield, VA 22161

13. SUPPLEMENTARY NOTES

NREL Technical Monitor: A. Lewandowski

14. ABSTRACT (Maximum 200 Words)

This report gives the conclusions drawn from a study of the potential application of high-temperature solar process

heat for production of aluminum.

\section{SUBJECT TERMS}

aluminum process technologies; solar process heat; concentrated solar energy

\begin{tabular}{l}
\hline \multicolumn{3}{|l|}{ 16. SECURITY CLASSIFICATION OF: } \\
\hline \begin{tabular}{l|l|l|}
\hline a. REPORT & b. ABSTRACT & c. THIS PAGE \\
Unclassified & Unclassified & Unclassified \\
& & \\
\hline
\end{tabular}
\end{tabular}

17. LIMITATION
OF ABSTRACT
UL

18. NUMBER
OF PAGES

19a. NAME OF RESPONSIBLE PERSON

19b. TELEPONE NUMBER (Include area code) 